\title{
Provider-related barriers to accessing emergency contraception in developing countries: A literature review
}

Katherine Williams

Population Council

Follow this and additional works at: https://knowledgecommons.popcouncil.org/departments_sbsr-rh

Part of the International Public Health Commons, Maternal and Child Health Commons, Obstetrics and Gynecology Commons, and the Social and Behavioral Sciences Commons How does access to this work benefit you? Let us know!

\section{Recommended Citation}

Williams, Katherine. 2011. "Provider-related barriers to accessing emergency contraception in developing countries: A literature review." Washington, DC: Population Council. 


\section{Provider-related Barriers to Accessing}

Emergency Contraception in Developing Countries A literature review

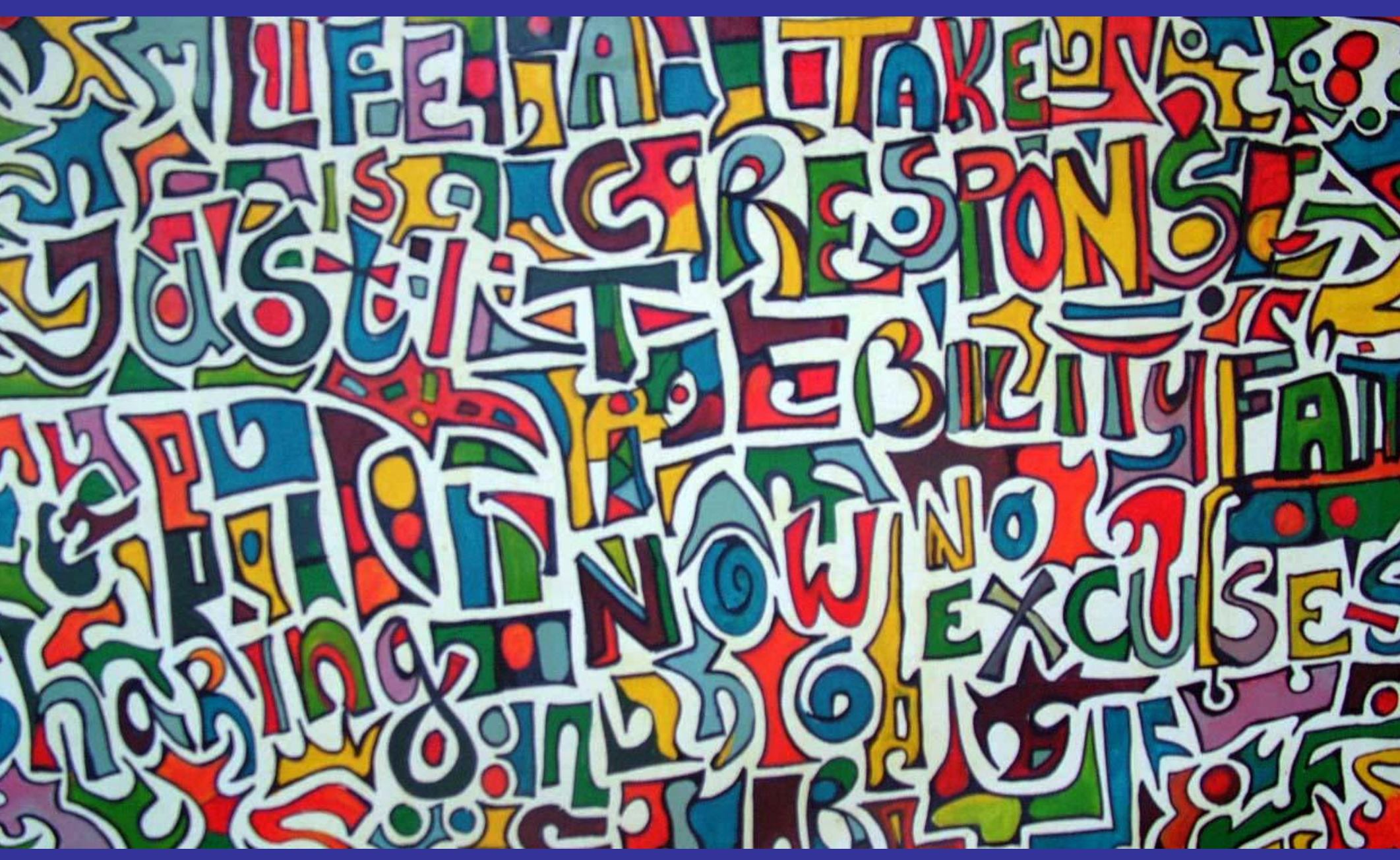





\title{
Provider-related Barriers to Accessing Emergency Contraception in Developing Countries: \\ A Literature Review
}

\author{
Katherine Williams
}

(2) Population Council 


\section{ACKNOWLEDGEMENTS}

This report benefitted from the contributions of numerous individuals and institutions. Firstly, I would like to acknowledge the authors of the documents included in this review, as this research would not have been possible without their well-conducted, and documented, program and research activities. I also would like to thank my colleague Martha Brady for her in-depth and substantive contributions to, and conceptualization of, the available evidence with particular regard to repeat use of emergency contraception. I would like to acknowledge the contributions of other colleagues at Population Council, including Saumya RamaRao, lan Askew, and John Townsend, for their guidance offered during this review's development and finalization. I am also appreciative of support provided by Elizabeth Westley of Family Care International who has helped frame this work in the larger context and contributed research, perspective, and data for consideration.

Finally, I gratefully acknowledge the support from the International Consortium for Emergency Contraception for this literature review and larger project, "Provider Beliefs, Attitudes and Practices Concerning Emergency Contraception." With concurrent activities at ICEC, FHI, Gynuity, and Population Council, this literature review intends to contribute to a global strategy for improving access to emergency contraception, and I am grateful for this opportunity to contribute to such a worthwhile aim.

\section{(1) Population Council The Population Council conducts research worldwide to improve policies, programs, and products in three areas: HIV and AIDS; Poverty, Gender, and Youth; and Reproductive Health.}

Published: June 2011

Population Council

4301 Connecticut Ave. N.W. suite 280

Washington, DC USA

Telephone: +1 2022379400

Facsimile: +1 2022378410

www.popcouncil.org

Suggested citation: Williams, Katherine. 2011. "Provider-related barriers to accessing emergency contraception in developing countries: A literature review." Washington, DC: Population Council.

(c) 2011 The Population Council, Inc. 


\section{TABLE OF CONTENTS}

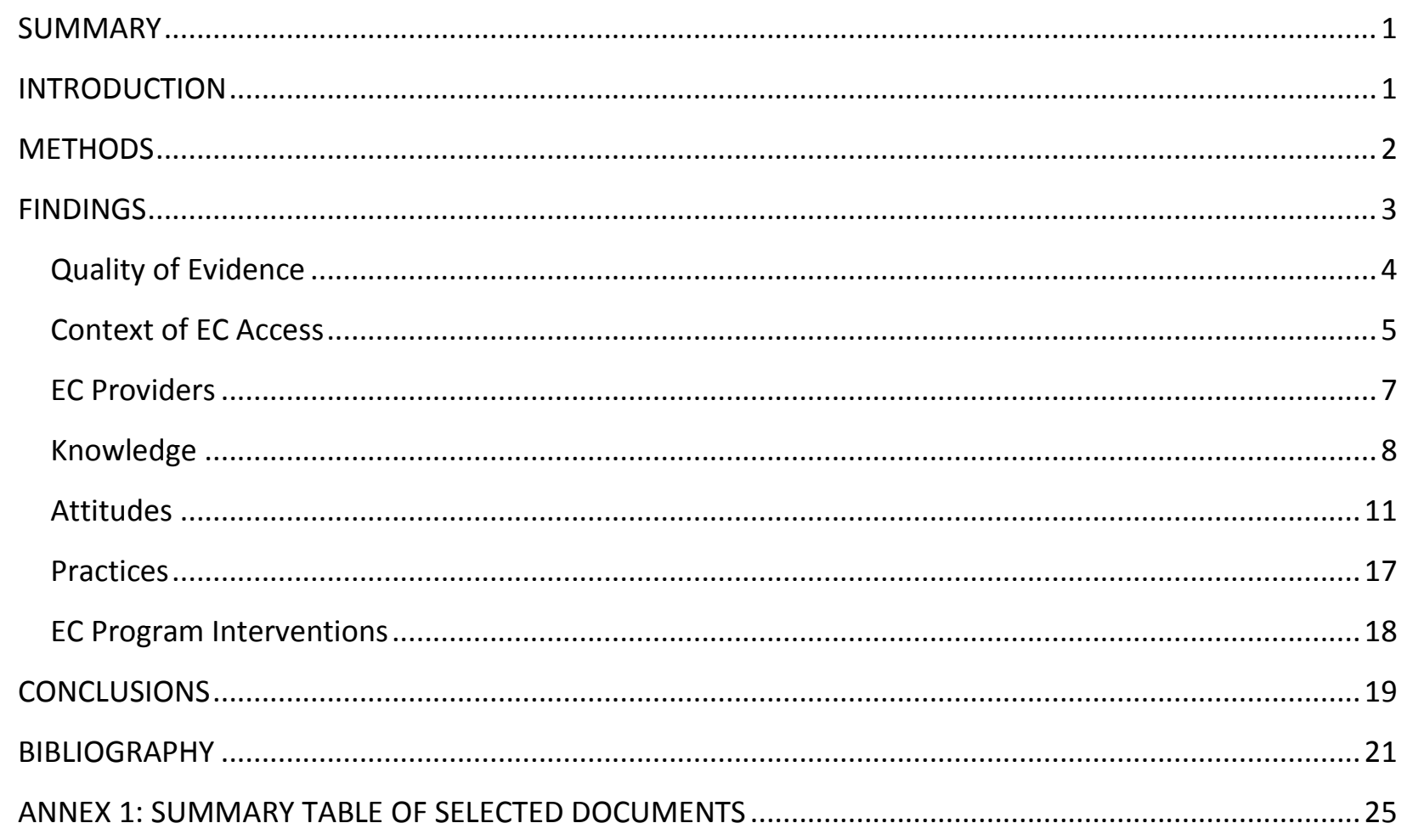




\section{SUMMARY}

Access to emergency contraception is affected by numerous variables, including systems-related, social, cultural, and legal factors. Provider-related barriers, including low levels of knowledge, negative or biased attitudes, and restrictive distribution practices directly limit availability of and access to emergency contraception and, ultimately, its utilization. This systematic literature review aims to identify and describe existing provider-related barriers to accessing EC in developing countries, as well as the prevalence of these barriers and documented research programs to address them. Findings from this review will contribute to specific recommendations on provider attitudes and behaviors related to emergency contraception and inform the development of a global advocacy strategy to increase access to the method.

\section{INTRODUCTION}

Emergency contraception (EC) has been in use for over 30 years, available across many countries and contexts in multiple formulations and offered through various access points. Emergency contraception include dedicated emergency contraceptive pills (ECP) such as levonorgestrel-only pills and ulipristal acetate; oral contraceptive pills in a specific timing and dosage sequence (called the Yuzpe method); and the insertion of a Copper T intrauterine device (IUD). These methods play a unique role in family planning programs in that they are they are the only effective methods to be used after sexual intercourse has occurred. Extensive research has demonstrated that emergency contraception is highly effective in preventing pregnancies and its access is an important component of all family planning program strategies.

Access to emergency contraception is influenced by numerous external variables in the United States and across the world. In developing countries, the issue of access is the most severe; in these countries, commodity supply outages, provider incompetency, lack of public awareness and misinformation often come together to restrict availability and access to all contraceptive methods, and emergency contraception in particular. Lack of knowledge among female populations certainly hinders demand for emergency contraception. Women's awareness of EC continues to be below 10 percent in Senegal and Zambia, and across the globe knowledge of EC is only around 20 percent (ICEC 2011a). Even in areas where studies show high levels of awareness, the actual use of the method remains low; in Kenya, for example, 40 percent of the population is aware of EC, yet only 2 percent of women report ever having used it (Central Bureau of Statistics 2004).

Barriers related to provider knowledge, attitudes, and practices are among the multitude of contextual and systematic limitations to accessing EC. Research studies have evaluated introduction of emergency contraception into new markets, assessed levels of knowledge and awareness among provider and 
client populations, and investigated social and cultural attributes affecting contraceptive product distribution, including EC. Providers' negative biases about providing EC, as well as lack of sufficient knowledge and motivation for counseling women on EC use, are postulated to affect provider distribution behaviors and, ultimately, women's acquisition of this method. Within the complex picture of emergency contraception access, addressing provider-related barriers serve as one way for improving the global picture of access.

To fully understand the extent of provider-related barriers, a systematic literature review was conducted for uncovering examples from a range of developing countries, focusing primarily on those from sub-Saharan Africa and South Asia, to investigate and document existing barriers. Barriers of particular interest include provider knowledge, attitudes, and practices associated with EC provision, such as negative biases toward giving or selling EC, lack of sufficient knowledge or motivation, external influences on distribution decisions and practices, as well as perceptions specifically concerning repeat or regular EC use. Findings from this review will inform specific recommendations for a background paper on provider attitudes and behaviors, and contribute to development of a global plan and advocacy strategy for emergency contraception.

\section{METHODS}

To ensure a comprehensive collection of documented research, clear and concise steps were followed in searching and aggregating findings from the literature on provider-related barriers. Beginning in January 2011, a key word search of PubMed (MEDLINE), Popline, and Google Scholar databases was conducted for identifying peer-reviewed and gray literature publications on the topic of interest. Key word search terms used are presented in Box 1. There was an interest in recovering research from a selection of countries, including Ethiopia, Ghana, India, Kenya, Nigeria, Rwanda, and Senegal, yet selected publications were not restricted to these countries only. The timeframe of articles selected for inclusion was between 2000 and April 2011. Bibliographies and reference lists from each identified publication were reviewed for identifying other potential articles, and subsequently, reference lists from those publications were also reviewed.

Additional websites, such as those from organizations with related research and programming experience, were reviewed for publications. Websites from the following organizations were included: International Consortium for Emergency Contracpetion (ICEC), Ibis International, FHI, PATH, Population Council, and PSI. The publications database on ICEC's website was also searched for relevant peer-reviewed and gray literature articles.

Box 1: Search terms used

Emergency contracept*

Provider terms: Provider/Provision; Pharmacist/Pharmacy; Midwife/Midwives; Nurse; Doctor; Drug-seller

Barrier terms: Barrier; Knowledge; Opinion; Belief; Perception; Attitude

Repeat Use: Repeat ; Routine

Country-specific: Ethiopia; Ghana; Kenya; India; Nigeria; Rwanda; Senegal 
Articles ultimately included in the literature review were those evaluating provider knowledge, attitudes, or practices concerning emergency contraception specifically, in the developing world. Four articles from Turkey and one from Puerto Rico were included in the selection of articles, as the classification module delineating developing countries is complex and non-specific, and the current situation and lessons from these two countries are relevant and applicable. In this review, all cadres were considered, including medical physicians, nurses, pharmacists, informal drug sellers, community health workers and other paraprofessionals, as well as police officers.

The following information was extracted from each article: authors and their institutions; study methodology; specific emergency contraception product studied and specific population of providers included in the study; context of EC availability in study setting; and lastly, detailed results regarding provider knowledge, attitudes, and practices. If the article highlighted a specific program intervention or one activity within a larger program, information about the larger program was also reviewed, when available. A summary of articles and documents included in this review is available in Annex 1.

Studies selected for this review used both quantitative and qualitative methods and included extended research documentation, as well as programmatic reviews, reports, and briefs. All relevant information and findings were reviewed and documented with respect to the following questions:

(i) Knowledge: Have providers heard of EC? Do they know the correct dose of EC and its correct timing? Do they know EC's mechanism of action? Do they believe EC to be an abortafacient? Are they aware of EC contraindications to EC use? Do they have "sufficient" knowledge for prescribing/providing EC correctly?

(ii) Attitudes: Do providers support provision or use of EC? In what circumstances do providers feel EC is appropriate (in case of unprotected sex, contraceptive failure/condom breaking, rape)? Are there particularities about EC support of EC use for adolescents, or particular scenarios when EC is deemed appropriate for adolescent use? Do providers believe EC increases promiscuous behaviors of its users? Do providers support advanced provision of emergency contraception? What are provider opinions and attitudes about repeat or routine use of emergency contraception?

(iii) Practices: Have providers ever distributed emergency contraception or EC-related counseling? Are they currently offering EC? How frequently are providers prescribing or selling EC? Do providers refuse to sell emergency contraception? What are the reasons for refusing to distribute $\mathrm{EC}$ ? Are there national guidelines or recommendations dictating to whom providers should distribute EC and for whom they are advised against distributing EC?

\section{FINDINGS}

A total of 298 articles were recovered from PubMed (Medline), Popline, and Google Scholar database searches. This number does not take into account duplicates from multiple search terms or from 
searches within different databases, yet is a comprehensive illustration of existing articles on this topic. Through the ICEC publications database and website searches, an additional 225 articles were recovered. Upon review of titles and publication dates of all identified publications, abstracts appearing to match search criteria were reviewed for relevance. Bibliographies and reference lists of selected articles were reviewed for further peer-reviewed publications, gray literature, and/or other relevant information. Thirty peer-reviewed journal articles and 13 gray literature documents were included in this review.

\section{Quality of Evidence}

Research articles identified in this review process include evidence from Latin America, Asia, and Africa. The quality of each study and evidence derived varies significantly. Not all studies included well-detailed procedures and information about tools used, scientific methods followed, or statistical analysis.

Quality of research presented in gray literature was, many times, equal and comparable to that presented in academic journals; and peer-reviewed articles did not fully represent the robust and highquality research available on this topic. Peer-reviewed articles included tend to be more clinic focused, outlining research studies and programs implemented in hospitals or clinic settings. In addition, academic articles were more likely one-time cross-sectional surveys implemented independent of a program and/or intervention. Programs or studies reviewing provision of EC outside of a facility, such as through pharmacies, community-based distribution, or by non-medical staff, were not identified as frequently within peer-reviewed publications and were more likely published in gray literature. For the sake of this review, it should be noted that research recovered in gray literature was generally as robust, informative, and relevant as that found in peer-reviewed journals; absence of a publication in a scientific peer-reviewed journal did not diminish merits of results.

Across all collected studies, methodologies and indicators were not consistent. The focus of most studies was EC providers, including medical and non-medical professionals, yet few studies sought information from clients, policy-makers, and advocates. Some studies employed structured questionnaires with open-ended or multiple-choice questions, and these questionnaires were, many times, conducted in an interview format, mailed, or hand-delivered to providers. Other methodologies included mystery clients and qualitative methods such as focus group discussions. A mixed-method approach was used in only a handful of selected studies.

As with methodology variability, researchers used different tools and indicators for evaluating similar information, and this created challenges for making comparisons across studies. As mentioned earlier, different questions were asked assessing provider knowledge, attitudes, and practices regarding emergency contraception. In addition, a few studies (Ebuehi et al 2006, Mondal et al 2006, Syahlul and Amir 2010) created their own scales for evaluating their results. These scales are one mechanism for determining whether providers were capable of adequately providing or counseling on EC, and although they are helpful for framing general and comprehensive understanding, comparison across different studies is not possible. Additional variability and limitations in pooling data and generalizing findings will be mentioned as each individual provider-related barrier is discussed in detail. 
For facilitating comparisons and visualizing trends in provider barriers, indicators common to multiple studies were compiled into graphical presentations. Indicators selected for comparison were not available in every study, yet were employed in a consistent and comparable manner in at least five separate studies in different geographical locations. These common indicators were reviewed and selected by experts in the fields of reproductive health and monitoring and evaluation. Common indicators were selected based on their attributes and relevance to results of interest; further information about these common indicators is detailed below.

These comparisons do not intend to serve as direct analogies or comparisons of one study's findings to another but intend to illustrate the wide scope of findings on provider knowledge, attitudes, and practices across the world. Additional quantitative and qualitative findings complement this information and contribute to a generalized picture of provider-related barriers, including knowledge, attitudes, and practices. These findings reveal trends, lessons, and next steps for informing a global strategy.

\section{Context of EC Access}

As is common for any contraceptive method, EC access is a complex picture, with variables and influences affecting supply and demand, legality and regulations, as well as awareness and support among all stakeholders. Local and national policies affect EC availability by regulating whether public sector facilities are allowed to provide the method, as well as whether providers are trained on correct provision. According to ICEC, emergency contraception is typically only offered through private sector facilities, demonstrated in studies from Barbados, Kenya, and Thailand (ICEC 2011b; Obare et al 2009; Ratanajamit 2001; Yam et al 2007). In addition, a survey among Ministries of Health revealed that, although EC is available in 80 percent of countries, only 46 percent of responding countries reported EC offered through public sector facilities (ICEC 2011). As part of the public sector distribution network, EC may be included in a national family planning program, as demonstrated in Bangladesh, Ghana, and Nigeria (Khan and Hossain 2008; Kishore et al 2010; Steiner et al 2000; Ebuehi et al 2006).

In addition to regulating policies, religious, social and cultural influences affect provider beliefs and behaviors, and vary significantly across regions. A detailed look into different contextual influences on EC availability is in Box 2.

In Latin America, dedicated EC products are marketed in some countries, through public and private markets. Oral contraceptives are available in most Latin American countries, many times accessible over the counter, and other times requiring a prescription. The prevalence of conservative cultural and religious norms affect service delivery policies, and EC provision is generally restricted to cases of rape or sexual assault. Social marketing activities in the early 2000s increased general awareness and distribution in Venezuela, Bolivia, Peru, Ecuador, and Argentina (Parker 2005), and additional movements for improving restrictions on reproductive health products and programs are underway. 


\section{Box 2: Detailed Context of EC Access}

Different EC Methods: There is more than one type of emergency contraceptive method. Dedicated products include levonorgestrel-alone pills, specially packaged for EC use only. The Yuzpe regimen entails taking regular oral contraceptive pills in a specific dose and timing, and copper intrauterine devices (IUDs) may be inserted within 72 hours of unprotected intercourse for use as EC. Yuzpe was the primary EC method in India (Tripathi et al 2003); in Turkey (Mandiracioglu et al 2003; Sevil et al 2006; Uzumer et al 2005; Zeteroglu et al 2004); and is currently the primary method in Uganda (Association of Obstetrics and Gynecology 2010). A lack of registration and labeling for emergency use of oral contraceptive pills (OCP) in Nigeria was shown to cause provider fears and reluctance for prescribing the method, before a dedicated EC product was introduced (Adekunle et al 2000; Adenkunle et al 2001). Ideally, optimal access to and delivery of EC entails availability and registration of a dedicated product (ICEC 2011,) and EC products available continues to increase across the globe.

Conservative Influences: Conservative cultural values and political systems affect EC availability and impressions. In Chile and Mexico, the Catholic Church and conservative political sectors play strong roles in framing social opinions and attitudes towards sexuality, women's health, and provider comfort with EC provision (Diaz et al 2003). In some countries, EC services are restricted to use in rape only (Diaz et al 2003). Outlandish media reports and misconceptions about EC are frequently present in media across the globe and have had significant effects on public and provider opinions, as well as EC legality in some cases (AGOU 2010).

Inclusion in National Family Planning Programs: Where EC is integrated into national family planning programs, access tends to increase. EC was introduced into India's National Family Welfare Program in 2003 and made available over the counter in 2005 (Kishore et al 2010). In 2006, Nigeria adopted family planning guidelines integrating EC, conducted dissemination and educational sessions for the general public, and made EC products available over the counter (Ebuehi et al 2010). Public sector access to these methods improves availability, decreases stigma, and promotes EC as part of general and comprehensive family planning services. Yet, in many cases, inclusion in public sector guidelines is not enough to increase use. In South Africa, as documented by Maharaj (2008), EC is "available but not accessible (or promoted) to women who rely on public sector for health services." Additional efforts are necessary for improving availability and decreasing barriers to access.

Pharmacy Access: In Kenya, private sector pharmacies are the main avenue for obtaining EC (Obare 2009). Pharmacy access to EC sometimes requires a doctor's prescription, such as in Barbados, Indonesia, Ghana, and South Africa (Yam et al 2007; Syahlul and Amir 2010; Steiner et al 2000; Hariparsad 2001b). In Jamaica, pharmacy access to $E C$ is possible on the condition the pharmacist counsels the woman about $E C$ at purchase (Yam et al 2007). Despite pharmacy access increasing availability, questions remain about quality of service and counseling provided by pharmacists. Pharmacies can provide adequate EC services on par with those offered through other medical facilities, and in some cases, users actually prefer accessing EC through pharmacies (Skibiak et al 2001). Challenges remain for pharmacists in maintaining quality EC services, specifically those associated with FP counseling with required degree of intensity or depth expected, lack of space and privacy available in some pharmacy facilities, and demand from concurrent customers (Skibiak et al 2001). 
Across Africa, EC access is steadily increasing, with many governments integrating EC in national family planning service delivery policies and guidelines, and offering the method within public sector services. Access is increasingly focused on distribution through private market delivery mechanisms including pharmacies and medicine shops. In Kenya, private sector pharmacies account for as much as 94 percent of EC sales (Obare et al 2009). A broad range of dedicated products are available across the continent, yet myths and misconceptions in the media have played a significant negative role in EC awareness and public approval. In Uganda, negative media actually resulted in illegalization of a once-approved EC method (Association of Obstetrics and Gynecology of Uganda, 2010).

EC access across Asia depends greatly on product legality and registration and individual countries' incorporation of EC within national systems, as well as availability within private markets. India approved EC use in 2001, and multiple dedicated products are now available freely in government dispensaries, private markets, and pharmacies. As a comparison, no emergency contraceptive pill was registered or approved in Laos at the time of Sycharuen's recent study (2010), inaccessible through both public and private sectors, with few providers even aware of the method.

\section{EC Providers}

The range of providers distributing EC is broad in the collected literature. This makes it difficult to generalize about specific cadres of providers, yet there are multiple studies evaluating knowledge, attitudes, and practices of numerous types of providers within one area. In addition, trends and commonalities do appear among different service providers within specific topics of interest.

In summary, physicians were the most frequently studied population of providers. Collected research demonstrated gynecologists (Ob/Gyns) tend to be more knowledgeable and have more positive attitudes about EC compared to other cadres of physicians, including primary health care specialists, general practitioners, and community physicians. In public clinics of Addis Ababa, Ethiopia, Ob/Gyns are more knowledgeable about EC, more likely to have counseled on EC, and more likely to have provided EC compared to other types of physicians (Kassaye and Dwizedi 2009). In Jamaica, Ob/Gyns expressed most liberal attitudes about EC provision, and fewer negative attitudes about the method compared to nurses and pharmacists (Yam et al 2007).

In many countries, nurses and midwives are main sources of EC within the public sector. EC provision by paramedical workers, including auxiliary nurse midwives, and lady and male health workers, is common in public sector distribution in India and Bangladesh, and despite initial low levels of knowledge among paraprofessionals, paramedical and field workers in Bangladesh achieve equal levels of knowledge as physicians upon training. In addition, paraprofessionals ultimately provide higher quality EC services than their physician counterparts (Khan and Hossain 2008).

In contrast to India, where physicians demonstrate significantly greater levels of EC knowledge than pharmacists (Kishore et al 2010), pharmacists in South Africa exhibit both efficient knowledge as well as strong distribution practices (Blanchard et al 2005) at comparable levels to physicians, in certain cases (Hariparasad 2001a). In addition, a program intervention in Zambia gave young women the option of receiving EC and associated counseling from a range of sources, including pharmacies, youth clubs, 
community organizations, and peer counselors, and demonstrated that when given the choice, all women (as well as young women aged 15-24) prefer seeking EC information (54 percent) as well as EC supplies (74 percent) from pharmacies (Skibiak et al 2001). Non-pharmacists workers, such as drugsellers, distribute a large proportion of EC in Thailand, Cambodia, Kenya, and Nicaragua (PATH 2004; Ratanajamit 2001), and it has been documented the majority of pharmacy services may be provided by lesser-trained drug sellers and front-line workers.

When integrated into sexual violence services, emergency contraception and sexual and reproductive health services can be provided by non-medical providers, including police officers. As part of a comprehensive response to sexual violence in Ethiopia and in Zambia, police officers were trained in safely and effectively providing EC and referring gender-based violence survivors to further health and legal services. This model demonstrated success in EC provision and referral (Keesbury et al 2009), and its potential in other geographic areas is currently being investigated.

\section{Knowledge}

Assessments of provider knowledge about emergency contraception across studies revealed great variability by type of provider, and within different contexts of EC availability. To evaluate provider knowledge, many study protocols included a question asking providers if they had ever heard of EC. Responses showed a range in knowledge, from only one in four Ethiopian police officers (Kassa et al 2009) and 34 percent of urban Ghanaian physicians, to 90 percent or more of providers in Turkey (Sevil et al 2006), Indonesia (Syahlul and Amir 2010), Barbados, and Jamaica (Yam et al 2007), who reported hearing about the method.

According to WHO, EC pills will help prevent pregnancy when a woman takes the method up to five days (120 hours) after unprotected sex (WHO 2007). Knowledge of this correct period of time for EC effectiveness was frequently asked of providers in surveys and interviews. Visualization of these collated results can be seen in Figure 1, demonstrating a wide range of comprehension about EC diagnosis guidelines in four different geographic regions: Africa (orange), South Asia (yellow), Latin America (dark blue), and Turkey (light blue). For this data, no difference in provider knowledge is apparent between regions, yet the large variance in results is noteworthy in itself. As few as 19 percent of pharmacists in Puerto Rico, and as many as 89 percent of pharmacists in South Africa, and 99 percent of providers in Bangladesh, knew the correct time period for EC administration. Providers in Turkey were generally less informed about correct timing of EC, while general knowledge (ever hearing about the method) was actually relatively high (Sevil et al 2006). In addition to the results represented below, 22 percent of family medicine providers in Karachi, Pakistan were unsure of correct timing for EC effectiveness (Abdulghani et al 2009). This uncertainty and proportions of providers unfamiliar with this information reiterates need for additional training and educational efforts informing EC providers about correct provision procedures. 


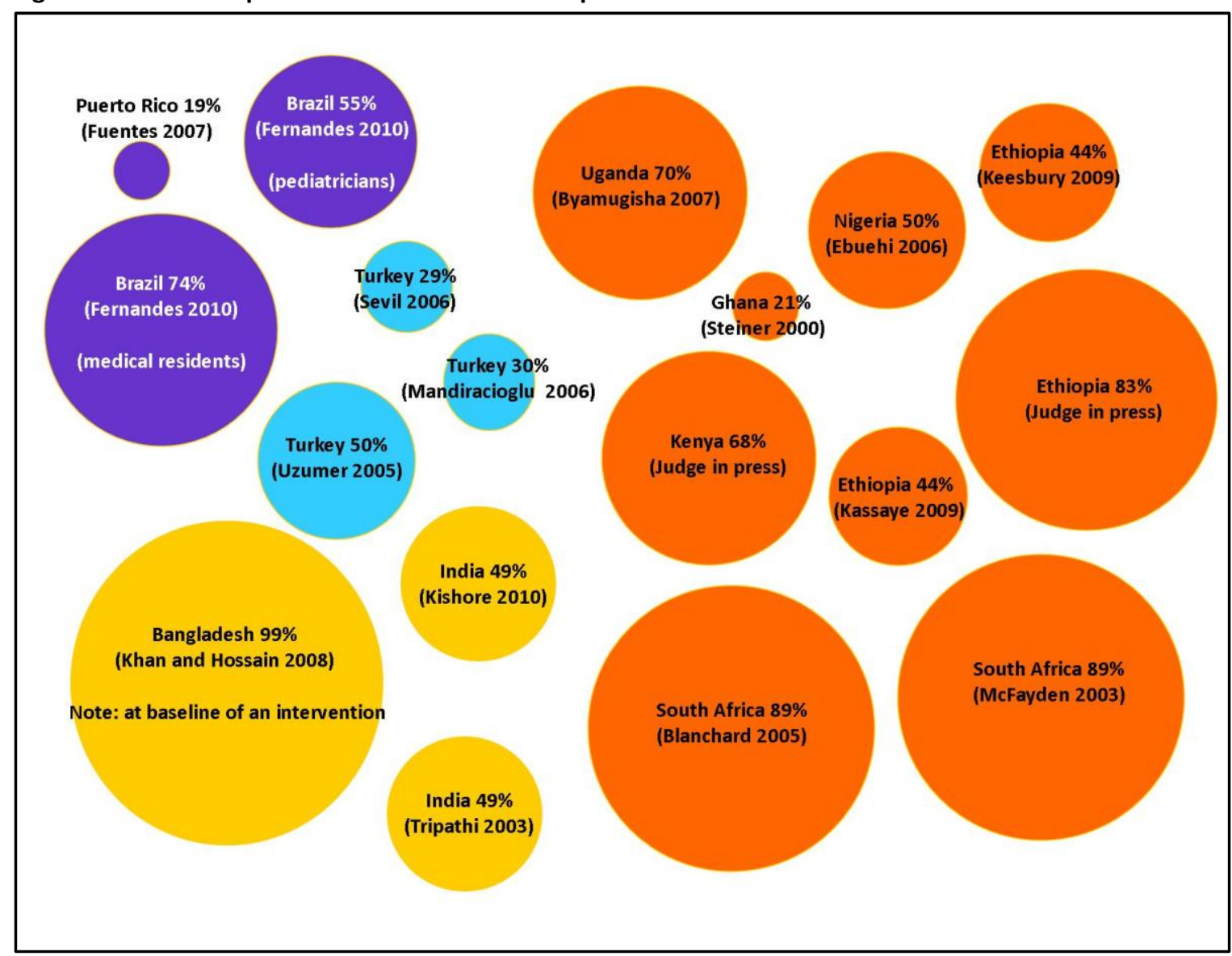

When analyzing this information, it is important to note correct timing for EC dosing may change with specific method and is not always consistent between product instructions and national and international recommendations. For instance, among providers in the Caribbean (Yam et al 2007), only seven percent in Jamaica and one percent in Barbados were able to identify the correct period for EC administration after unprotected sex (120 hours). Nonetheless, the majority of providers (58 percent in Barbados and 72 percent in Jamaica) indicated the correct period as 72 hours, which was the indication in the EC package instruction labeling when the study was conducted.

Proper understanding of EC's mechanism of action is another indicator representing provider EC knowledge. According to ICEC and the International Federation of Gynecology \& Obstetrics (FIGO), emergency contraceptive pills interfere with ovulation and may possibly prevent sperm and egg from meeting (ICEC 2011c). As many as 27 of 33 (89 percent) South African pharmacists correctly identified the method's function in inhibiting ovulation, fertilization, or implantation, while only 17 percent of Kenyan nurses and midwives were able to do the same (Judge et al 2011). Despite continued evidence demonstrating EC's mechanism of action, many providers mistakenly believe emergency contraception is, or works in the same way as, an abortafacient. As seen in Figure 2, as many as 54 percent of providers in Bangladesh incorrectly classified EC as an abortafacient before they participated in training (Khan and Hossain 2008). This misunderstanding was also prevalent among a smaller proportion of providers in 
Turkey, Ghana, and Nigeria (Uzuner et al 2005; Steiner et al 2000; Ebuehi et al 2006), and 42 percent of providers interviewed in Pakistan were "unsure" whether EC was or was not an abortafacient (Abdulghani et al 2009). Scientific evidence suggests EC does not interrupt established pregnancy and does not prevent implantation of a fertilized egg (ICEC 2011c). Providers in Ethiopia were more aware of this evidence, and only one percent of untrained providers in Keesbury and colleagues' intervention program identified EC as an abortafacient (Keesbury et al 2007). Very few providers interviewed in Chile and Mexico considered EC a "micro-abortion" (Diaz et al 2003).

Figure 2: Percent providers who believe EC to be an abortafacient

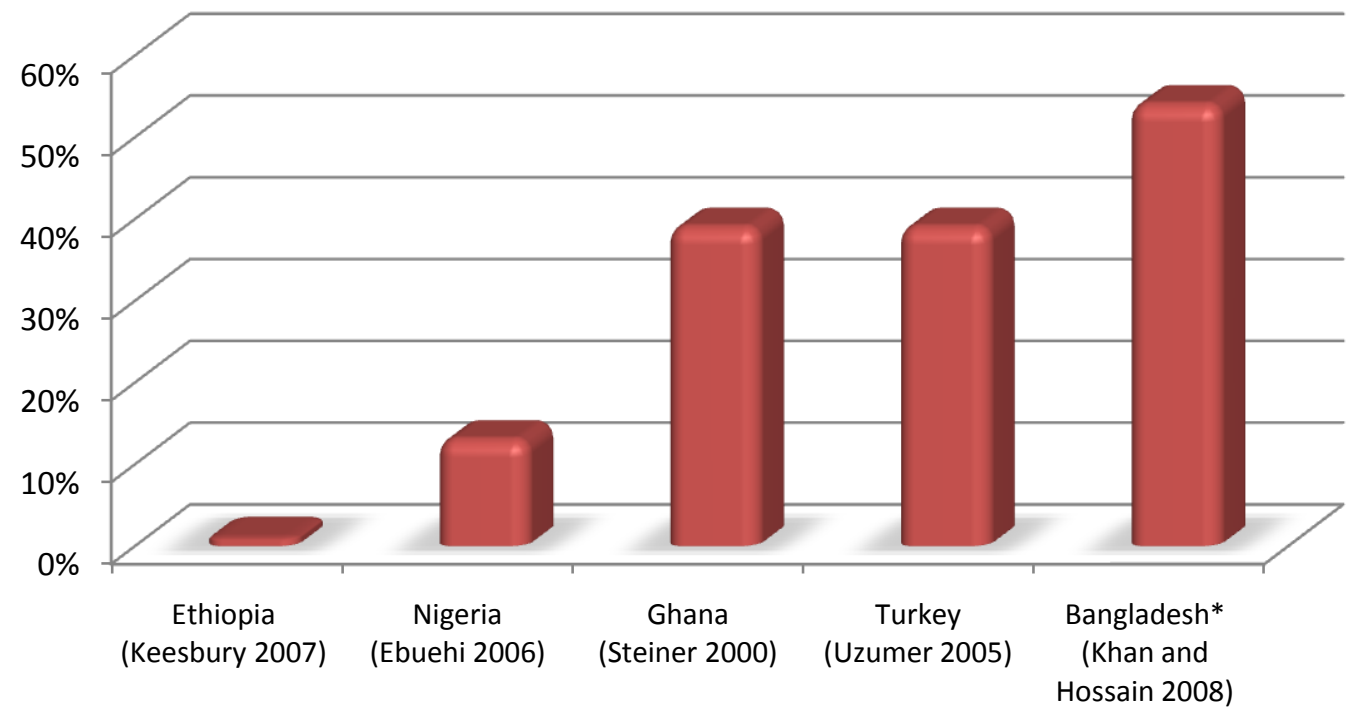

Note: * indicates data from baseline study of a program intervention. At endline, percent of providers believing EC was an abortafacient was $6 \%$.

A few studies included in this review developed their own scales assessing provider EC knowledge including provider understanding of timing, dosage, side effects, and proper utilization, among other topics. Because each scale's composition was unique to each study, they cannot be easily compared, yet illustrating a sample of these results does provide insight into provider capacity for proper counseling and provision for EC. In Brazil, 22 percent of surveyed medical residents, and 63 percent of physicians, were able to accurately describe all steps entailed in correctly prescribing EC (Fernandes et al 2010). In contrast, none of the 92 providers reporting some level of knowledge about the method in Ghana could accurately describe its use regimen (Steiner et al 2000). In Nigeria, 24 percent of providers were considered to have "good" knowledge (correctly answering at least 16 of 19 questions about EC), while only 10 percent of surveyed providers could describe the correct name, dose, and timing for correct EC administration (Ebuehi et al 2006). In this same study, differences between cadres of providers were apparent: 35 percent of physicians had "good" knowledge, while only 23 percent of community health workers, 15 percent of pharmacists, and 15 percent of nurses did. In Thailand, where knowledge was evaluated using a weighted score, non-pharmacist workers (i.e. drug sellers) scored an average of 25 on a scale of 60 points (42 percent) while pharmacists scored an average of 36 out of 60 (60 percent). 
Though not common throughout all studies, some literature indicated providers held misconceptions about EC. Some providers believed EC has contraindications including diabetes, breast feeding, cigarette smoking, breast cancer, heart disease, liver disease, and thrombosis (Steiner et al 2000; Yam et al 2007). WHO guidelines currently state that there are no contraindications to EC's use (WHO 2007). In addition, some providers were unfamiliar with EC's legal status in their country: Only 30 percent of providers in Nigeria knew EC was legal and included in the nation's family planning guidelines (Ebuehi et al 2006); fewer than 50 percent of providers In Keesbury's study knew EC was legal in Kenya (2007). More could be done for ensuring providers are informed of current family planning policies as well as methods available, and legal, for provision.

Overall, when providers were asked whether they were confident in their EC comprehension, many agreed they needed more information for adequately providing EC. Specifically, in Turkey, among 140 providers interviewed in primary health care clinics, only 19 percent felt they had adequate information about the method, and 84 percent wanted to learn more (Sevil et al 2006). This sentiment was also seen in Uganda (Byamugisha et al 2007).

\section{Attitudes}

Provider attitudes, opinions, and biases about EC represent what providers truly believe, including their support or opposition to provision, and opinions potentially affecting distribution practices. Some studies collected indicators capturing providers' general level of EC approval. Where evaluated, EC approval was generally high, ranging from 64 percent of providers in Ethiopia (Kassaye and Dwizedi 2009) to 76 percent among Ghanaian providers familiar with the method (Steiner et al 2000). Opposition to EC has also been documented: 21 percent of providers in Ghana actively opposed EC use, and providers identifying as Catholic were nearly twice as likely (odds ratio of 1.8) to oppose the method than those from other religions. Overall, acceptance of the method among providers is encouraging, yet more specific insights into attitudes are warranted.

Providers had different impressions about which circumstances warranted, or were appropriate for, EC use. Global guidelines state all women can use EC after unprotected sex and is appropriate for use among women in any scenario where unprotected sex has occurred (WHO 2007). Figure 3 presents the proportion of providers, in multiple studies, who felt EC was appropriate for use in the following three cases: rape, contraceptive failure, and unprotected sex.

Results in the figure demonstrate providers are generally more supportive of EC use in cases of rape than in cases of contraceptive failure or unprotected sex. The lowest proportion of providers supporting EC use in the case of rape was 55 percent, among gynecologists in India (Tripathi et al 2003), and was highest (97 percent) among trained providers in Ethiopia (Keesbury et al 2009). Although not unanimous, support for EC in the case of rape was always more than half in provider populations. Different cadres of providers in Tripathi's study vocalized different perspectives: 14 percent of medical students, 33 percent of paramedical providers, 55 percent of gynecologists, and 83 percent of general practitioners supported use of EC in cases of rape (2003). 
Figure 3: Percent of providers who consider EC appropriate for rape, contraceptive failure, and unprotected sex

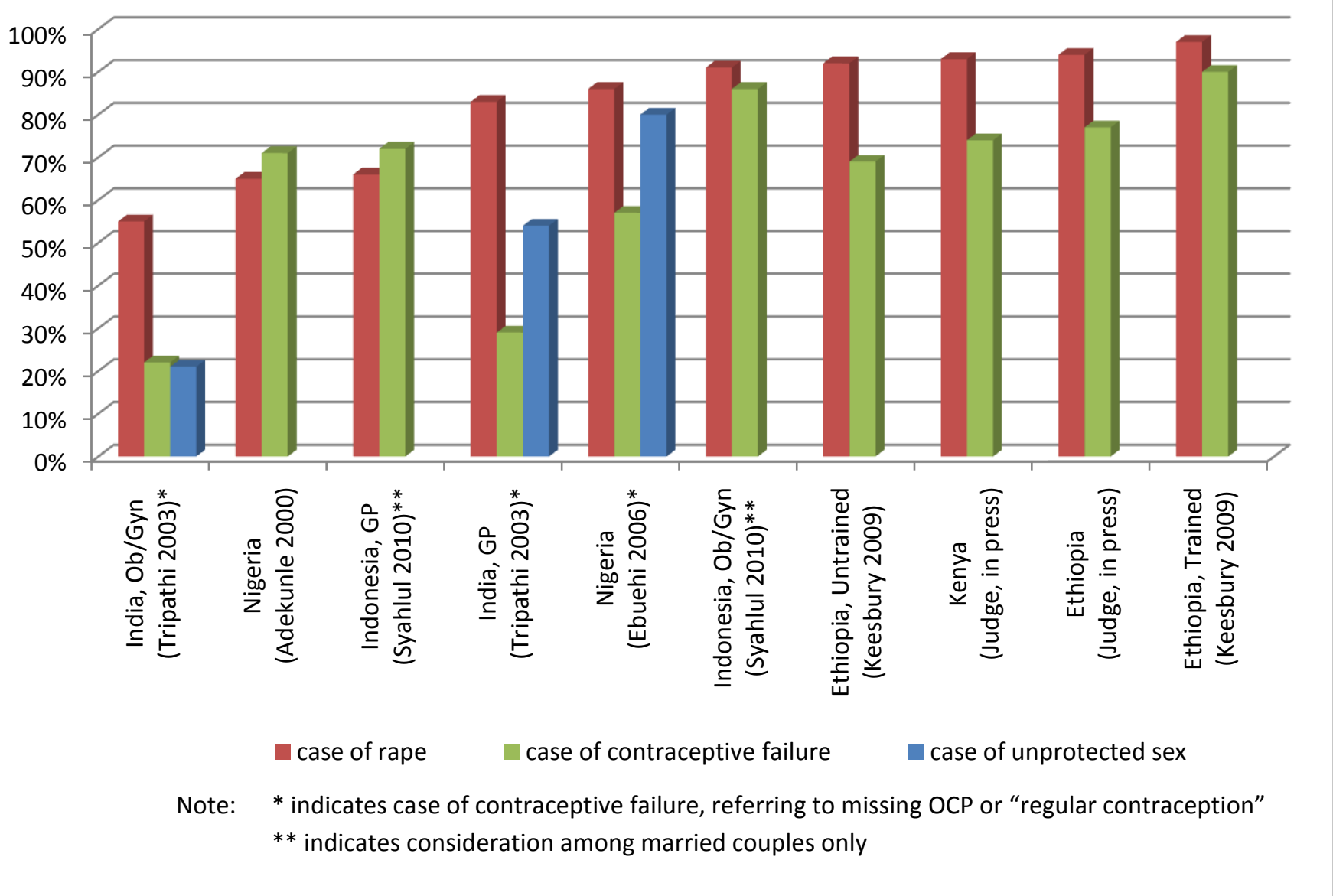

Supportive attitudes about EC use in cases of contraceptive failure and unprotected sex were consistently lower among providers. In eight of the ten studies presented in the figure, approval in cases of rape was higher than for contraceptive failure. In Tripathi's study, only 22 percent gynecologists supported EC use in case of contraceptive failure (specifically condom rupture), and only 21 percent supported EC use after "unprotected sex." These variations indicate the extent of potential EC provision is not yet well understood by providers. There is need for provider awareness and support of EC provision in all scenarios protecting women from unintended pregnancy, particularly as cases of rape are encountered less often than contraceptive failure.

These differences have also raised question about how providers define "unprotected sex." As depicted in the literature, provider understanding of unprotected sex may be perceived as women's intentional non-use of contraception during sex. In actuality, an act of unprotected sex is not contingent on a woman's intentions of contraceptive use and may occur in any scenario, including instances of contraceptive failure as well as rape. Further clarification of these terms, including sources of these perceptions and definitions, would be of interest for researchers, for better comprehension of provider biases and barriers. 
Concerns about EC safety and side effects appeared to make some providers hesitant in providing the method. When inquired, 58 percent of providers in Pakistan had significant concerns about "side effects or teratogenicity" (Abdulghani et al 2009), and similar concerns, albeit at lower levels, were documented in Ghana and Mexico (Heimburger et al 2002, Steiner et al 2000).

Opinions about repeat or recurrent use of EC tend to spark conservative and negative opinions among providers in the collated literature. Repeat use is generally framed as a negative occurrence, and providers tend not to support its use more than once. In Brazil, a qualitative report from a physician explained, "a woman should not be abusing [EC], repeating this as a regular contraceptive method" (Diaz et al 2003). These attitudes and practices may be influenced by international recommendations, social and cultural influences, or tone and context of provider training curricula. Details of provider attitudes regarding repeat use are presented in Box 3.

Many providers believe EC use affects women's sexual behaviors, namely increasing promiscuity and sexual risk taking, and decreasing utilization of other contraceptive methods. Providers in multiple reviewed studies held this belief, as demonstrated in Figure 4, wherein more than half of providers surveyed in Kenya, Barbados, Jamaica, and India felt EC use would increase user promiscuity. These beliefs varied considerably among different cadres of providers as well (not portrayed in Figure 4). In Jamaica, specifically, 16 percent of ObGyns, 48 percent of general practitioners, 77 percent of nurses, and 85 percent of pharmacists believed EC encouraged sexual risk taking, and trends among providers in Barbados were similar (Yam et al 2007). Conservative cultural influences may help shape provider misunderstandings and biases in Kenya and Ethiopia.

Figure 4: Percent of providers, by country, who believe women's use of EC will increase promiscuity

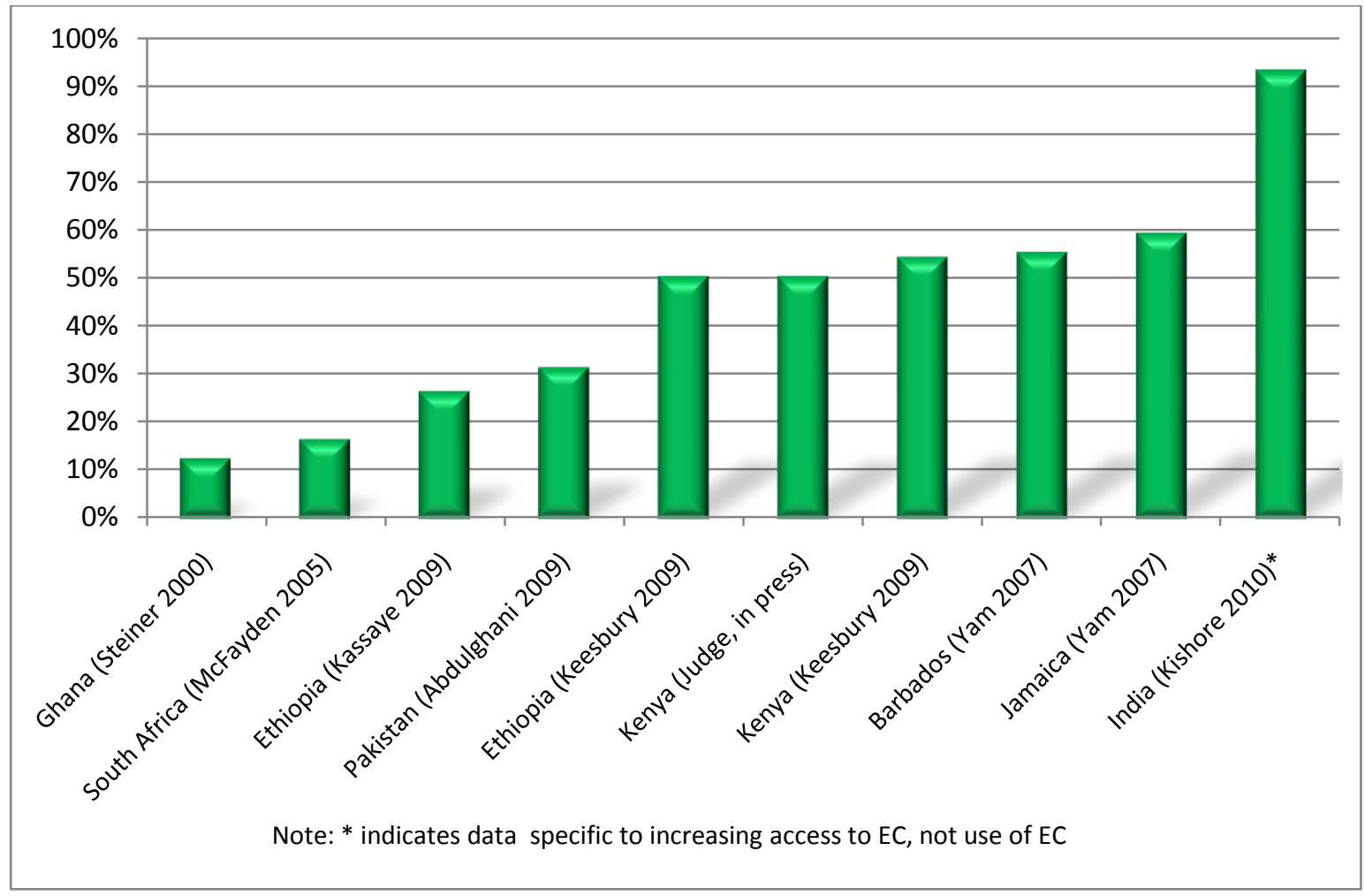




\section{Box 3: Repeat use of emergency contraception}

Opinions about repeated or recurrent EC use continue to remain unsettled, as policymakers, providers, and women themselves express concerns (Abuabara et al 2004). Scientific evidence concerning EC use multiple times demonstrates routine use is safe and poses no health risks to women (WHO 2007). When used repeatedly, its efficacy is considered "reasonable" (Halpen et al 2010; Shelton 2002) and recent findings demonstrate pregnancy protection lower than other methods (35 percent chance of pregnancy using combined EC, and 20 percent using progestin-only EC (Trussel and Raymond 2011). Yet, repeated use does not reduce efficacy-EC is equally as effective each time (ICEC 2011c). Current WHO Medical Eligibility Criteria (MEC) states recurrent EC use is an indication women require further counseling on other contraceptive options (WHO 2009).

\section{Use of EC as a regular or routine method of contraception}

According to studies, EC is not considered a regular contraceptive method, such as oral pill or IUD. Providers feel EC "is reserved for special or exceptional situations" (Brazil, Fernandes et al 2010); "should not be used as a substitute for regular contraception" (Laos, Sychareun et al 2010); and women who use EC should "learn to use family planning" (Senegal, Diop 2009). Among 228 providers surveyed in Jamaica, 97 had refused to prescribe or sell EC in the past, 43 percent of whom refused because the client had recently used the method (Yam 2007). In Latin America and South Africa, providers feel there should be a maximum number of times a woman should be given EC (Fernandes et al 2010; Hariparsad 2001a; McFayden et al 2003), as low as two or three in Western Cape, South Africa (although the specific timeframe for this was not available).

\section{Safety of repeated use}

Provider concerns about negative health consequences and safety of EC exist for one time use and, more often, when considering recurrent use. Current WHO MEC state no contraindications to EC pills' repeated use unless women have conditions contraindicated for combined or progestin-only hormonal methods. 85 percent of pharmacists in Puerto Rico did not know repeated EC use does not cause health problems (Fuentes and Azize-Vargas 2007), and providers in other areas fear side effects including breast and ovarian cancers (Diaz et al 2003; Sychareun et al 2010). Providers in South Africa agreed using EC a couple times a year is more risky to women's health than oral pills (Blanchard 2005). 54 percent of pharmacists and 40 percent physicians in another study agreed that use of EC multiple times was more risky than oral pills on a regular basis (Hariparsad 2001a).

\section{Guidelines and curriculum depiction of repeat use}

Recurrent EC use is usually presented as a negative occurrence in guidelines and training curricula. With current research demonstrating EC safety and effectiveness (Abuabara et al 2004; Halpern et al 2010) and that contraceptive choice is ultimately the client's, providers should expect women may need EC multiple times during their reproductive years (Abuarbara et al 2004; Shelton 2002). From studies included in this review, guidelines in Bangladesh (Khan and Hossain 2008), India (Mondal et al 2006), Kenya (Keesbury et al 2007), and Uganda (AOGU 2010) discourage repeated EC use, and studies in these countries considered providers' agreement with the statement "EC cannot be used as a regular method" as positive reflection of their knowledge base. National recommendations and guidelines should certainly adhere with global recommendations, and family planning experts do not currently recommend women should use any form of EC as regular contraceptive method. However, without adequate evidence to support restrictions on repeated EC use, providers should be instructed to discuss the complete range of family planning options with clients in order to select the most appropriate contraceptive method satisfying their needs. 
Qualitative results collected from general practitioners and gynecologists from Indonesia complement these findings: The majority of providers there believe EC encourages intercourse among unmarried couple, that it may lead to "free sex," and its use will increase rates of sexually transmitted infections. Concerns are significantly more apparent when providers consider teenage and adolescent use (Syahlul and Amir 2010). More optimistically, fewer than half of providers in Pakistan, Ethiopia, South Africa, and Ghana (as seen in Figure 4) express these misconceptions about EC.

In attempt to fully comprehend the extent of negative attitudes among providers, it is important to realize the intricacies and particularities of data presented in Figure 4. Results presented for each of these studies are not entirely equivalent and intend to depict the range of results, more than serving as tools for comparison. For example, 12 percent of providers in Ghana who believe EC will increase women's promiscuity does not equate to 88 percent of providers there not having this perception (Steiner et al 2000). In actuality, 12 percent represents the percentage of providers listing "promotes casual unprotected sex" among reasons for opposing EC use, and only 21 percent of 325 providers opposed EC use, while 76 percent favored it.

Regarding beliefs about EC's effect on other contraception method use, 60 percent of pharmacists in South Africa's private sector believed increasing EC availability would decrease user utilization of barrier methods (Hariparsad 2001b). Sixty-five percent of providers in another South African study vocalized concern that EC promotion would negatively affect uptake of long-term contraceptive methods (McFayden et al 2003). Qualitative data in Brazil, Mexico, and Chile revealed concerns among providers about undesirable behaviors and decrease in contraception and condom use as women started to use EC (Diaz 2003). In Uganda, 54 percent of providers believed condom use would decline as family planning clients became aware of EC (Byamugisha et al 2007); and in two separate studies from Turkey, 75 percent and 80 percent of providers believed the same negative correlation existed between EC and condom use (Uzumer et al 2005; Sevil et al 2006).

Proportions of providers in the following countries vocalized concern that EC use would lead to increased rates of sexually transmitted infections: Uganda (Association of Obstetrics and Gynecologists of Uganda 2010), South Africa (Hariparsad 2001b), Turkey (Sevil et al 2006; Uzumer et al 2005), Barbados, and Jamaica (Yam et al 2007).

Provider support for, or opposition to, advanced provision of emergency contraception is another aspect of provider attitudes about EC. Advanced provision involves providing EC beforehand, in case unprotected intercourse occurs. Some providers feel advanced provision increases user access to the method and are supportive, yet fears exist among some providers, fears that women may "abuse" the method, use it repeatedly or "too frequently," that advanced provision may increase risky sexual behavior or sexually transmitted infections and discourage use of other more reliable contraceptive methods. While 90 percent of providers in Kenya supported "greater access to the method," only 29 percent of providers supported advanced provision (Muia et al 2002). Support was slightly higher in Ghana and Mexico, at 42 percent and 44 percent, respectively (Steiner et al 2000; Heimburger et al 2002), and more than one half of providers surveyed in Uganda (54 percent) and Ethiopia (68 percent) were in favor of advanced provision (Byamugisha et al 2007; Kassaye and Dwizedi 2009). In South Africa, 
sentiments were dependent on women's marriage status, with only one quarter (29 percent) of pharmacists supporting advanced provision for unmarried women, and over one half ( 53 percent) supported provision for married women (Blanchard et al 2005). Although the range is wide, it seems providers in many studies were supportive of advanced provision.

As mentioned, provider attitudes about EC use among adolescents and youth are even more conservative than those regarding the general population. Rates of approval for EC provision to adolescents were low in Ghana (51 percent), South Africa (41 percent), and Nigeria (32 percent) (Steiner et al 2000; Blanchard et al 2005; Ebuehi et al 2006), and in general, providers are less supportive of EC utilization among a younger population. Providers in some areas feel age restrictions should be placed on EC use. In Jamaica, providers felt the minimum age should be an average of 15.6 years, and in Barbados, an average of 16.6 years (Yam et al 2007). Providers in Brazil felt informed consent from parents should be necessary before dispensing EC to adolescents (Fernandes et al 2010). In Kenya, training private pharmacists did not assuage provider fears about adolescent EC misuse if given access: 48 percent of trained providers and 55 percent of untrained providers believed EC use promoted promiscuity among young people. These sentiments and hesitations were even greater when considering EC provision to adolescent boys (Keesbury et al 2009; Keesbury et al 2007). Qualitative data from Laos is consistent with findings from Latin America and Africa, including beliefs that youth would forget to use condoms if the method were "too convenient," and frequency of unsafe and unplanned sex would increase (Sychareun et al 2010). Compilation of these research findings demonstrates moderately negative perspectives on adolescent EC provision. Outliers do exist, such as trained nurses and midwives in Ethiopia, of whom 64 percent supported EC provision to adolescent populations (Keesbury et al 2009), yet need for targeted training and sensitization about youth reproductive health needs is necessary.

An interesting and important note, regarding adolescent and youth populations in the literature, is that results seemed to frame author opinions and attitudes about unmarried adolescents specifically and did not provide much detail about provider attitudes and perceptions concerning married adolescents. Studies investigating provider attitudes about married adolescents using EC were not found in the literature. It would be of interest to see if provider opinions about EC use were any different when considering married young women, particularly in countries where large numbers of girls are married at a young age, such as Ethiopia, Nigeria, or Laos (PRB 2007).

Correlation between provider attitude and knowledge was evident in the literature: As knowledge levels increased, attitudes about the method became more positive and supportive. Qualitative data collected in Brazil revealed a general discomfort among providers about dispensing EC to some clients because of admitted lack of knowledge about the method (Fernandes et al 2010). EC legality and availability was also postulated to affect provider attitudes, and researchers speculated conservative attitudes and misconceptions observed among nurses in Jamaica contributed to their lack of authority for writing prescriptions for the method (Yam et al 2007). Increasing knowledge, availability, and authority for distributing the method may go a long way in overcoming provider-related EC barriers. 


\section{Practices}

Researchers are interested in provider knowledge and attitude about emergency contraception and its use because they ultimately determine provider distribution practices for the method. Unlike indicators illustrating provider knowledge and attitudes, however, information representing EC provider practices are not easily comparable. Some indicators and survey questions evaluating EC distribution and counseling are not informative. As examples, "Have you ever provided EC?" and "Are you currently providing EC?" are easy to understand, yet do not provide much detail about distribution or inform an overall picture of access.

Practice indicators, such as frequency of EC provision, provide a specific time for conceptualizing EC provision distribution, yet formats of frequency questions vary across studies. For example, 38 percent of Jamaican pharmacists and 51 percent of Barbadian providers reported distributing EC within the past one month (Yam et al 2007), while 23 percent of providers in Ghana reported providing EC within the past year (Steiner et al 2000), and pharmacists in South Africa report selling an average of 177 pills per year (Hariparsad 2001b). Differences in measurement hinder comparison. Depending on the indicator, EC distribution rates may be perceived as very high or very low. While 94 percent of nurses and clinic managers from primary health care centers in three South Africa provinces reported offering EC, only 36 percent of these providers reported offering the method within the past three months (McFayden et al 2003). In general, data on EC provision demonstrate relatively low rates of distribution in most countries and by most providers. Question and data collection format differences make comparisons challenging.

Without appropriate and comparable indicators, provider distribution practices may be inferred from other information. This is possible because, firstly, correlation between provider knowledge, attitudes, and behaviors has been demonstrated in many studies in this review, and secondly, other social and legal factors have been shown to directly affect provider distribution practices. An analysis of these relationships provides, at the least, an indirect illustration of provider EC distribution trends and behaviors.

Noted through anecdote, as well as statistically evaluated, provider distribution practices are documented as directly relating to their knowledge and attitudes of EC: Increased levels of knowledge, as well as more positive and approving attitudes, about EC are associated with increased provision of the method. In Kenya, analysis revealed providers with higher levels of knowledge were significantly more likely to counsel patients on EC (with an odds ratio of 1.75) and were over three times more likely to provide the method (odds ratio of 3.3). Those with strong biases against the method were significantly less likely to ever have provided the method (odds ratio of 0.54) (Judge et al 2011). In Indonesia, providers reporting prescribing oral contraceptives in the six months prior to the survey were more likely to have "very good" knowledge (particularly about Postinor-2) and were also more likely to approve of over-the-counter access to EC (Syahlul and Amir 2010). In Pakistan, one third (31 percent) of physicians associated their reluctance in prescribing EC (and discomfort counseling clients) with their general inexperience with the method (Abdughani et al 2009). Similar findings were documented in India (Kishore et al 2010), among pharmacists in Thailand and Puerto Rico (Ratanajamit 2001; Fuentes 2007), and in Uganda (Byamugisha 2007), where 78 percent of providers confirmed they would increase EC provision if they had more knowledge about the method. 
Contextual, legal, and social factors influence provider distribution practices. This is the case in Latin America, where provider opinions are affected by current political influences and conservative culture, and some fear repercussions from providing EC if it is not clearly stated, in policy and on the package itself, that EC is not an abortafacient (Diaz 2003; Fuentes 2007). Respect for legal and regulatory restrictions, as well as fear of legal repercussions from dispensing a non-registered product, dictate behaviors in other countries. In Nigeria, among reasons for refusing to dispense EC, 15 percent of providers report "avoiding litigation" as the primary rationale for not distributing it (Adekunle et al 2001). In South Africa, most pharmacy EC distribution requires a prescription from a doctor and, nonetheless, 62 percent of pharmacists report providing the method without prescription, either ignorant of or intentionally contravening the law (Hariparsad 2001b). Clearly, contextual and regulatory environments framing reproductive health policy affect provider provision of $\mathrm{EC}$, and willingness to provide it.

Where emergency contraception is heavily regulated or illegal, advocacy and awareness-raising efforts should be the primary focus of any intervention or program. Efforts for improving political support for EC, assurance of its legality, as well as method registration and supply, must be in place before implementing training or provider-related programs.

\section{EC Program Interventions}

In efforts to increase EC access, program interventions address the complete range of issues negatively affecting access and availability implemented in public and private sectors, and on pilot and nationallevels. Among interventions in the literature addressing provider-related barriers specifically, EC training is the most common, either as stand-alone programs, integrated within larger reproductive health curricula, or as one component within multi-dimensional programs.

Provider training (including training of trainers) results in improved knowledge, attitudes, and behaviors about EC. In Kenya, contraceptive technical updates (CTUs) training included information and technical guidance, and showed significant effect on provider knowledge of EC, and favorable attitudes towards the method. In addition, CTU-trained providers were more likely to bridge EC users to other family planning methods, and a CTU-trained provider in facilities increased overall performance of facilities in general (Keesbury et al 2009). Provider training in Bangladesh, Ethiopia, and India each demonstrated similar improvements in EC knowledge, attitudes, and provision behaviors (Khan and Hossain 2008; Khan et al 2004; Keesbury et al 2007). When revisited four months, and then two years, after initial training, physicians and paraprofessionals continued providing high-quality EC counseling and provision in Bangladesh and India, and 96 percent of Bangladesh providers knew correct EC initiation timing (Khan et al 2004; Khan and Hossain 2008). Consensus among researchers about the importance and potential of training providers is reflected in discussions in many reviewed articles, and multiple authors commented on importance of training and/or recommended improvements for number and quality of trainings for health providers (Blanchard et al 2005; Keesbury et al 2009; Khan and Hossain 208; Yam et al 2007).

Social media and demand-creation campaigns may affect EC awareness among providers and clients, and may contribute to improved knowledge, attitudes, and practices. Awareness-raising activities 
targeted directly at providers have shown increased knowledge and supportive behaviors in Albania (Volle et al 2009) and Kenya (Keesbury et al 2009), yet evaluating these types of interventions are difficult, as there are likely multiple external and confounding factors affecting observed change. In addition, it is unlikely awareness-raising campaigns make observed change in provider practices on their own without additional activities overcoming barriers, such as procurement, legal, or logistical.

In Zambia, EC provision was assigned to trained police officers as part of a multi-sectoral sexual and gender-based violence intervention increasing EC availability (Keesbury et al 2009). Alongside community outreach, supervision, and improvements to the referral chain between police and health sectors, extensive training and supervision was provided to police officers. As a result, EC knowledge among police officers improved, and the number of EC accessed by violence survivors also increased. Replication and scale-up of this model is currently underway.

Working with larger health systems for overcoming existing provider barriers and improving EC availability and access has shown results in multiple settings. In Bangladesh and India, as part of national movements introducing EC into family planning programs, multiple coinciding and long-standing activities were implemented to improve EC awareness, increase political support, train providers, and ensure wide availability of the product. Programs in Bangladesh and India demonstrated significant improvement regarding provider-related barriers, whereby an increase in political support for EC was established, paving way for further activities to increase access. Advocates and stakeholders changed national guidelines for not only including EC as a recognized family planning method but also increasing the cadres and numbers of eligible providers (to include nurses, health workers) for dispensing EC (Khan et al 2004; Khan and Hossain 2008). As a result of these mainstreaming activities, providers were more knowledgeable about EC, government was supportive, and clients accessed more comprehensive EC services (Khan and Hossain 2008).

Mainstreaming activities in Kenya and Ethiopia utilized similarly comprehensive approaches, including training public and private providers and equipping them with materials facilitating thorough provision of EC and reproductive health services. In these two programs, provider trainings demonstrated the most significant effects on provider knowledge, attitudes, and behaviors towards EC (Keesbury et al 2007; Keesbury et al 2009). Additional program components such as awareness-raising campaigns, technical support for public and private sectors, and product registration efforts worked symbiotically, contributing to a general improvement in EC access.

\section{CONCLUSIONS}

From the evidence collated in this literature review, it is clear that provider knowledge, attitudes, and practices affect women's access to EC and are significantly variable across the existing literature. EC knowledge, including proper utilization and diagnostic guidelines, is central to positive and supportive provider attitudes and active provision. Studies demonstrate that providers continue to lack correct information and guidance about EC for facilitating correct provision. Conservative attitudes about EC are 
prevalent across different geographic areas and continue to persist even in areas where the method is widely available. When EC is supported by the government and well-known by the people, provider attitudes tend to be more supportive of distribution, yet hesitations and questions continue to raise concern among providers, policymakers, and women themselves. Conservative views and policies about the method greatly influence provider knowledge, frame attitudes, and inevitably, limit method provision.

Behaviors and practices associated with EC provision are more difficult to generalize, yet clear correlations exist between provider knowledge, attitudes, and practices. Improvements in knowledge and attitudes concerning EC have a positive effect on provider distribution behaviors. External influences, such as EC's legal status and policies regulating cadres of providers dispensing the method, or requirements for prescription, certainly affect availability. Cultural and religious influences, issues of stock and supply, and lack of political advocacy are beyond provider control. As part of a larger and comprehensive program, however, provider training has shown significant (and long-term) effect on improving provider-related barriers to EC access. Within the larger movement towards mainstreaming EC, provider-related barriers may be addressed with increased knowledge about, and appreciation for, emergency contraception.

Studies in this review varied in methodology, quality, and outcome. Available academic literature is more likely to include clinic-based studies and stand-alone cross-sectional analyses, and less likely to feature many community-level social science interventions in gray literature. There is certainly need for more research-in particular, research focused on programs and interventions demonstrating effect and impact. We currently know a lot about what providers know and what they believe. Of greater interest now is identifying evidence of successful and efficient models reducing provider-related barriers to access and the most effective methods to overcome them, in order to ultimately increase access to emergency contraception around the world. 


\section{BIBLIOGRAPHY}

Abuabara K, D Becker, C Ellertson, K Blanchard, R Schiavon, SG Garcia. As often as needed: Appropriate use of emergency contraceptive pills. Contraception 2004; 69: 339-342.

Abdulghani HM, SI Karim, F Irfan. Emergency contraception: Knowledge and attitudes of family planning physicians of a teaching hospital, Karachi, Pakistan. Journal Health Population and Nutrition 2009; 27(3): 339-334.

Adekunle AO, AO Arowojolu, AA Adedimeji, MA Okunlola. Emergency contraception: Survey of knowledge, attitudes and practice of health care professionals in Ibadan, Nigeria. Journal of Obstetrics and Gynaecology. 2000; 20(3):284-9.

Adekunle AO, IA Babarinsa, Z Akinyemi, AY Okediran. Legal and regulatory aspects of prescribing and marketing emergency contraception in Nigeria. African Journal of Medicine and Medical Sciences 2001; 30(1-2): 14350 .

Anderson C, A Blenkinsopp. Community pharmacy supply of emergency hormonal contraception: A structured literature review of international evidence. Human Reproduction 2006; 21(1): 272-284.

Aneblom G, CS Lundborg, A Carlsten, K Eurenius, T Tydén. Emergency contraceptive pills over-the-counter: Practices and attitudes of pharmacy and nurse-midwife providers. Patient Education and Counseling 2004; 55(1): 129-35.

The Association of Obstetricians and Gynecologists of Uganda (AOGU). Mainstreaming EC knowledge among inservice and pre-service health care providers in Uganda. 2010. Nairobi: AOGU/ ECAfrique/ Population Council.

Ball DE, N Marafie, E Abahussain. Awareness and perceptions of emergency contraception among retail pharmacists in Kuwait. Pharmacy World \& Science 2006; 28(2):101-6.

Beckman LJ, SM Harvey, CA Sherman, DB Petitti. Changes in providers' views and practices about emergency contraception with education. Obstetrics and Gynecology 2001; 97(6): 942-6.

Blanchard K, T Harrison, M Sello. Pharmacists' knowledge and perceptions of emergency contraceptive pills in Soweto and the Johannesburg Central Business District, South Africa. International Family Planning Perspectives 2005; 31(4): 172-178.

Byamugisha JK, FM Mirembe, E Faxelid, K Gemzell-Danielsson. Knowledge, attitudes and prescribing pattern of emergency contraceptives by health care workers in Kampala, Uganda. Acta Obstetricia Gynecologica Scandinovica. 2007; 86(9): 1111-6.

Card RF. Conscientious objection and emergency contraception. American Journal of Bioethics 2007; 7(6): 8-14.

Central Bureau of Statistics (CBS), Ministry of Health [Kenya] and ORC Macro. Kenya Demographic and Health Survey 2003. 2004.Calverton, Maryland: CBS, MOH, and ORC Macro.

Diaz S, E Hardy, G Alvarado, E Ezcurra. Acceptability of emergency contraception in Brazil, Chile, and Mexico: Perceptions of emergency oral contraceptives. Cadernos de Saúde Pública 2003; 19(5): 1507-17

Diop NJ, B Mane, O Faye, C Niang, T Thiaw, FB Mbow, Y Niang Faye. Enquete sur la contraception d'urgence au niveau des pharmacies. September 2009. Dakar: Population Council/ ECAfrique [article in Friench, abstract in English].

Ebuehi OM, OAT Ebuehi, V Inem. Health care providers' knowledge of, attitudes toward and provision of emergency contraceptives in Lagos, Nigeria. International Family Planning Perspectives 2006; 32(2): 89-93. 
Fernandes RF, MS de Souzza Vitalle, FC da Silva. Emergency contraception: What do pediatricians know about this subject? Minerva Pediatrics 2010; 62: 153-60.

Fuentes EC, Y Azize-Vargas. Knowledge, attitudes and practices in a group of pharmacists in Puerto Rico regarding emergency contraception. Puerto Rico Health Science Journal 2007; 26(3):191-7.

Halpen V, EG Raymond, LM Lopez. Repeated use of pre- and post-coital hormonal contraception for prevention of pregnancy. Cochrane Database of Systematic Reviews 2010, Issue 1.

Hariparsad N. Attitudes and practices of pharmacists towards emergency contraception in Durban, South Africa. European Journal of Contraception and Reproductive Health Care 2001(b); 6(2): 87-92.

Hariparsad N. Knowledge of emergency contraception among pharmacists and doctors in Durban, South Africa. European Journal of Contraception and Reproductive Health Care 2001(a); 6(1): 21-6.

Heimburger A, D Acevedo-Garcia, R Schiavon, A Langer, G Mejia, G Corona, E del Castillo, C Ellertson. Emergency contraception in Mexico City: Knowledge, attitudes, and practices among providers and potential clients after a 3-year introduction effort. Contraception 2002; 66: 321-329.

Hossain SMI, ME Khan, R Vernon, et al. ECP Handbook: Introducing and mainstreaming the provision of emergency contraceptive pills in developing countries. 2008. Washington, DC: Population Council.

International Consortium for Emergency Contraception (ICEC). “Improving Access to Emergency Contraception: Policy Statement." 2003. Washington DC: ICEC. Accessed on April 25, 2011 at $<$ www.emergencycontraception.org>

International Consortium for Emergency Contraception (ICEC). Emergency Contraceptive Pills: Medical and service delivery guidelines. 2004. New York: ICEC.

International Consortium on Emergency Contraception (ICEC). 2011a. Accessed on April 25, 2011 at $<$ www.emergencycontraception.org $>$

International Consortium for Emergency Contraception (ICEC). 2011b. “Emergency Contraception: How far have we come? What's new? What's next? Online discussion forum" March 2-16, 2011. Final Report. New York: ICEC.

International Consortium for Emergency Contraception (ICEC). 2011c. "Mechanism of Action: How do levonorgestrel-only emergency contraceptive pills (LNG ECPs) prevent pregnancy?” March 2011. New York: ICEC.

Judge S, A Peterman, J Keesbury. Provider determinants of emergency contraceptive counseling and provision in Kenya and Ethiopia. Contraception 2011; 83(5): 486-90.

Kassa M, YG Hiwot, A Abdella. Barriers to accessing emergency contraception by victims of sexual assault in Addis Ababa, Ethiopia. Ethiopian Journal of Reproductive Health 2009: 3 suppl 1; 24-30.

Kassaye T, AD Dwizedi. Seeking ways in improving promotion and provision of emergency contraception in Addis Ababa hospitals. Ethiopian Journal of Reproductive Health 2009: 3 suppl 1; 44-51.

Keesbury J, H Aytenfisu, S Bradford. Mainstreaming emergency contraception in Ethiopia's public sector. Final Report. 2007. Addis Ababa: Federal Republic of Ethiopia/ Ethiopian Society of Obstetricians and Gynecologists/ ECAfrique/ Population Council.

Keesbury J, H Aytenfisu, T Mekbib, T Belay, et al. Mainstreaming EC in Ethiopia's public sector: Project results and implications for scale-up. Ethiopian Journal of Reproductive Health 2009; 3 suppl 1: 4-15.

Keesbury J, W Liambila, F Obare. Mainstreaming emergency contraception in Kenya. Final Project Report. 2009. Nairobi: Population Council/ EC Afrique. 
Keesbury J, B Owino, S Bradford. Emergency contraception, female condoms and IUDs in Kenya's public sector: Findings from a National Diagnostic Assessment. Final Report. 2007. Nairobi: Population Council/ ECAfrique/ Ministry of Health Kenya/ UNFPA.

Keesbury J, M Zama, S Shreeniwas. The Copperbelt model of integrated care for survivors of rape and defilement: Testing the feasibility of police provision of emergency contraceptive pills. 2009. Lusaka: Population Council/USAID.

Khan ME, SMI Hossain. Introducing and scaling-up delivery of emergency contraceptive pills in the National Family Planning Program of Bangladesh. 2008. Washington, DC: Population Council/ USAID.

Khan ME, SMI Hossain, MN Bhuiyan. "Building national capacity to delivery emergency contraception services in Bangladesh." Research Update 3, 2005. New Delhi: Population Council/ USAID.

Khan ME, SMI Hossain, M Rahman. Introduction of emergency contraception in Bangladesh: Using operations research for policy decisions. Final Report. 2004. Washington, DC: Population Council/ USAID.

Kishore V, MM Misro, D Nandan. Providers' knowledge, attitude and dispensing practices of e-pills in government dispensaries of South District in Delhi, India. Indian Journal of Community Medicine 2010; 35(1): 46-51.

Kumar S, C Shekhar, NK Gupta, M Roy, ME Khan, et al. Provision of emergency contraceptive services through paraprofessionals in India. Final Report. 2007. Washington, DC: Population Council/ USAID

Maharaj P, M Rogan. Emergency contraception in South Africa: A literature review. European Journal of Contraception and Reproductive Health Care 2008; 13(4): 351-61.

Mandiracioglu A, V Mevsim, O Turgul. Health personnel perceptions about emergency contraception in primary health-care centers. European Journal of Contraception and Reproductive Health Care 2003; 8(3): 145-9.

McFayden L, J Smit, M Mqhayi, H de Pinho, M Beksinska. Expanding contraceptive choice: An Africa study of emergency contraception. 2003. Witwatersrand, South Africa: Reproductive Health Research Unit.

Mondal A, D Ghosh, SL Seal, C Bose, AK Chakraborty. Knowledge, attitude and practices of emergency contraception among beneficiaries and providers. Journal of the Indian Medical Association 2006; 104(10): 551-3.

Muia E, K Blanchard, M Lukhando, J Olenja, W Liambila. Evaluation of an emergency contraception introduction project in Kenya. Contraception 2002; 66: 255-260.

Obare F, J Keesbury, W Liambila. The provision of emergency contraceptives in private sector pharmacies in urban Kenya: Experiences of mystery clients. African Population Studies 2009; 24(1).

Neville H, Golden et al. Emergency contraception: Pediatricians' knowledge, attitudes, and opinions. Pediatrics 2001; 107(2): 287-292.

Parker C. Adolescents and emergency contraceptive pills in developing countries. FHI Working Paper Series. 2005. Durham, NC: Family Health International.

PATH. "Increasing Access to Reproductive Health Services through Pharmacists." Outlook 2004: 21(2). Seattle: PATH.

PATH. “Increasing Youth Access to Services." Directions in Global Health 2004: 1(1). Seattle: PATH.

Population Council. Mainstreaming EC in Africa: The facilitative re-granting program. Final Narrative Report. 2009. Nairobi: Population Council/ ECAfrique.

Population Reference Bureau (PRB). 2006. PRB World's Youth 2006 Data Sheet. Washington, DC: PRB. 
Ratanajamit C, V Chongsuvivatwong. Survey of knowledge and practice on oral contraceptive and emergency contraceptive pills of drugstore personnel in Hat Yai, Thailand. Pharmacoepidemiol Drug Safety 2001; 10(2): 149-56.

Sevil U, E Yanikkerem, S Hatipoglu. A survey of knowledge, attitudes and practices relating to emergency contraception among health workers in Manisa, Turkey. Midwifery 2006; 22(1): 66-77.

Shelton J. Repeat emergency contraception: Facing our fears. Contraception 2002; 66(1): 15-17.

Skibiak JP, M Chambeshi-Moyo, Y Ahmed. Testing alternative channels for providing emergency contraception to young women. Final Report. 2001. Nairobi: Population Council.

Steiner MJ, E Raymond, JD Attafuah, M Hays. Provider knowledge about emergency contraception in Ghana. Journal of Biosocial Science. 2000; 32(1): 99-106.

Syahlul DE, LH Amir. Do Indonesian medical practitioners approve the availability of emergency contraception overthe-counter? A survey of general practitioners and obstetricians in Jakarta. BMC Women's Health 2005; 5: 3.

Sychareun V, K Phongsavan, V Hansana, A Phengsavanh. Policy maker and provider knowledge and attitudes regarding the provision of emergency contraceptive pills within Lao PDR. BMC Health Services Research 2010; 10: 212.

Tripathi R, AM Rathore, J Sachdeva. Emergency contraception: Knowledge, attitude, and practices among health care providers in North India. J of Obstetrics and Gynecology Research 2003; 29(3): 142-6.

Trussell J, EG Raymond. Emergency contraception: A last chance to prevent unintended pregnancy. 2011. Accessed at <ec.princeton.edu/questions/ec-review.pdf> on April 1, 2011.

Uzuner A, P Unalan, M Akman, S Cifcili, I Tuncer, E Coban, H Yikilkan, T Akgun. Providers' knowledge of, attitude to and practice of emergency contraception. European Journal of Contraception and Reproductive Health Care 2005; 10(1): 43-50.

Volle J, M Murthi, A Cicolli, T Gryboski. Albania family planning. Improving access and use of modern contraception among young men and women. Final Report 2009. Washington: C-Change/ AED/ USAID.

Yam EA, G Gordon-Strachan, G McIntyre, H Fletcher, SG Garcia, D Becker, E Ezcurra. Jamaican and Barbadian health care providers' knowledge, attitudes and practices regarding emergency contraceptive pills. International Family Planning Perspectives 2007; 33(4): 160-167.

World Health Organization Department of Reproductive Health and Research (WHO/RHR) and Johns Hopkins Bloomberg School of Public Health/ Center for Communication Programs (CCP), INFO Project. Family Planning: A Global Handbook for Providers. 2007. Baltimore and Geneva: CCP and WHO.

World Health Organization (WHO), United Nations Development Programme/United Nations Population Fund/World Health Organization/World Bank Special Programme of Research, Development and Research Training in Human Reproduction, Task Force on Post-Ovulatory Methods of Fertility Regulation. Efficacy and side effects of immediate postcoital LNG used repeatedly for contraception. Contraception 2000; 61: 303-8.

World Health Organization (WHO), Department of Reproductive Health and Research. Medical eligibility criteria for contraceptive use, fourth edition. 2009.

Zeteroglu S, G Sahin, HA Sahin, G Bolluk. Knowledge and attitudes towards emergency contraception of health-care providers in a region with a high birth rate. European Journal of Contraception and Reproductive Health Care 2004; 9(2): 102-6. 


\section{ANNEX 1: SUMMARY TABLE OF SELECTED DOCUMENTS}

\section{Peer-reviewed journal articles included in the review}

\begin{tabular}{|c|c|c|c|c|}
\hline Author (vear) & Country/ Program & Study design & Type of providers & Outcomes \\
\hline $\begin{array}{l}\text { Abdulghani et al } \\
(2009)\end{array}$ & Pakistan & $\begin{array}{l}\text { Cross-sectional questionnaire with } 45 \text { providers } \\
\text { conducted through interviews }\end{array}$ & $\begin{array}{l}\text { Physicians, residents, and medical } \\
\text { officers }\end{array}$ & $\begin{array}{l}\text { Provider knowledge, attitudes and } \\
\text { practices about EC. }\end{array}$ \\
\hline $\begin{array}{l}\text { Blanchard et al } \\
(2005)\end{array}$ & South Africa & $\begin{array}{l}\text { Cross-sectional study including provider } \\
\text { questionnaire administered by interview with } 34 \\
\text { providers in } 28 \text { pharmacists. }\end{array}$ & Pharmacists & $\begin{array}{l}\text { Provider knowledge, attitudes and } \\
\text { practices about EC, }\end{array}$ \\
\hline Diaz et al (2003) & $\begin{array}{l}\text { Brazil, Mexico and } \\
\text { Chile }\end{array}$ & $\begin{array}{l}\text { Focus group discussions with } 35 \text { health providers; } \\
\text { Interviews with } 78 \text { policy-makers and authorities. }\end{array}$ & $\begin{array}{l}\text { Health providers working in public } \\
\text { and NGO sectors in economically } \\
\text { deprived areas }\end{array}$ & $\begin{array}{l}\text { Provider knowledge, attitudes and } \\
\text { practices about EC }\end{array}$ \\
\hline Ebuehi et al (2006) & Nigeria & $\begin{array}{l}\text { Cross-sectional self-administered questionnaire } \\
\text { with } 256 \text { providers. }\end{array}$ & $\begin{array}{l}\text { Physicians from public and private } \\
\text { sectors, nurses, pharmacists, and } \\
\text { community-health workers }\end{array}$ & $\begin{array}{l}\text { Provider knowledge, attitudes and } \\
\text { practices about EC, including } \\
\text { comparison across different cadres of } \\
\text { providers }\end{array}$ \\
\hline $\begin{array}{l}\text { Fernandes et al } \\
(2010)\end{array}$ & Brazil & $\begin{array}{l}\text { Semi-structured self-completion questionnaire } \\
\text { with } 19 \text { open-ended and multiple choice } \\
\text { questions. }\end{array}$ & $\begin{array}{l}\text { Pediatric residents and pediatricians } \\
\text { participating in an adolescent-health } \\
\text { training. }\end{array}$ & $\begin{array}{l}\text { Provider knowledge, attitudes and } \\
\text { practices about EC, including } \\
\text { adolescent use. }\end{array}$ \\
\hline $\begin{array}{l}\text { Fuentes and Azize- } \\
\text { Vargas (2007) }\end{array}$ & Puerto Rico & $\begin{array}{l}\text { Cross-sectional descriptive study with self- } \\
\text { administered questionnaire administered to } 367 \\
\text { providers }\end{array}$ & Pharmacists & $\begin{array}{l}\text { Provider knowledge, attitudes and } \\
\text { practices about EC }\end{array}$ \\
\hline
\end{tabular}




\begin{tabular}{|c|c|c|c|c|}
\hline Author (vear) & Country/ Program & Study design & Type of providers & Outcomes \\
\hline Hariparsad (2001a) & South Africa & $\begin{array}{l}\text { Questionnaire administered to providers in private } \\
\text { sector facilities of Durban, including } 112 \\
\text { pharmacists and } 151 \text { physicians. }\end{array}$ & Pharmacists and physicians & $\begin{array}{l}\text { Provider knowledge and practices } \\
\text { about EC, }\end{array}$ \\
\hline Hariparsad (2001b) & South Africa & $\begin{array}{l}\text { Questionnaire administered to providers in private } \\
\text { sector facilities of Durban, including } 112 \\
\text { pharmacists and } 151 \text { physicians. }\end{array}$ & Pharmacists and physicians & $\begin{array}{l}\text { Provider attitudes and practices about } \\
\text { EC }\end{array}$ \\
\hline $\begin{array}{l}\text { Heimburger et al } \\
\text { (2002) }\end{array}$ & $\begin{array}{l}\text { Mexico/ Mainstreaming } \\
\text { activity (1997-2000) } \\
\text { included IEC, } \\
\text { workshops, public info } \\
\text { campaigns, inclusion } \\
\text { of EC in national family } \\
\text { planning guidelines, } \\
\text { and promotion }\end{array}$ & $\begin{array}{l}\text { In-depth interviews with } 29 \text { providers in Mexico } \\
\text { City Mexfam clinics to evaluate change in KAP. } \\
\text { Descriptive statistics, logistic regression and } \\
\text { content analysis of open-ended questions. }\end{array}$ & $\begin{array}{l}\text { Physicians and other health } \\
\text { providers }\end{array}$ & $\begin{array}{l}\text { Provider knowledge, attitudes and } \\
\text { practices about EC, including } \\
\text { differences between before and after } \\
\text { mainstreaming activities. }\end{array}$ \\
\hline $\begin{array}{l}\text { Judge et al (in } \\
\text { press) }\end{array}$ & $\begin{array}{l}\text { Ethiopia and Kenya/ } \\
\text { Mainstreaming } \\
\text { projects to increase } \\
\text { access to EC }\end{array}$ & $\begin{array}{l}\text { Cross-sectional facility-based survey with } 524 \\
\text { providers in } 5 \text { provinces of Kenya, and } 121 \\
\text { providers in Ethiopia. Includes a component } \\
\text { analysis to establish knowledge scores and bias } \\
\text { indicators. Conducts logistical regression analysis } \\
\text { to examine likelihood of counseling and provision } \\
\text { of EC as outcome measures. }\end{array}$ & Nurses, midwives and physicians & $\begin{array}{l}\text { Provider knowledge, attitudes and } \\
\text { practices about EC, including } \\
\text { associations between knowledge, } \\
\text { attitudes and practices. }\end{array}$ \\
\hline Kassa et al (2009) & Ethiopia & $\begin{array}{l}\text { Provider survey; survey and interviews with police } \\
\text { officers to assess knowledge about EC, service } \\
\text { provision, and potential barriers to EC provision } \\
\text { after sexual assault. }\end{array}$ & $\begin{array}{l}\text { Health providers and police officers } \\
\text { in sampled area }\end{array}$ & $\begin{array}{l}\text { Provider knowledge and attitudes } \\
\text { about EC and sexual assault services }\end{array}$ \\
\hline $\begin{array}{l}\text { Kassaye and } \\
\text { Dwizedi (2009) }\end{array}$ & Ethiopia & $\begin{array}{l}\text { Cross-sectional descriptive survey on attitudes of } \\
445 \text { providers in Addis Ababa public hospitals }\end{array}$ & Physicians & $\begin{array}{l}\text { Provider knowledge, attitudes and } \\
\text { practices about EC, specifically routine } \\
\text { counseling and advanced provision of } \\
\text { EC }\end{array}$ \\
\hline $\begin{array}{l}\text { Keesbury et al } \\
(2009)\end{array}$ & $\begin{array}{l}\text { Ethiopia/ } \\
\text { Mainstreaming project } \\
\text { to integrate EC in } \\
\text { public sector }\end{array}$ & $\begin{array}{l}\text { Evaluation of Mainstreaming project included } \\
\text { provider interviews and knowledge, attitudes and } \\
\text { practices survey for providers before and after } \\
\text { training. }\end{array}$ & Mainly nurses and midwives & $\begin{array}{l}\text { Provider knowledge, attitudes and } \\
\text { practices about EC, including changes } \\
\text { in KAP with training and } \\
\text { implementation of intervention } \\
\text { activities }\end{array}$ \\
\hline
\end{tabular}




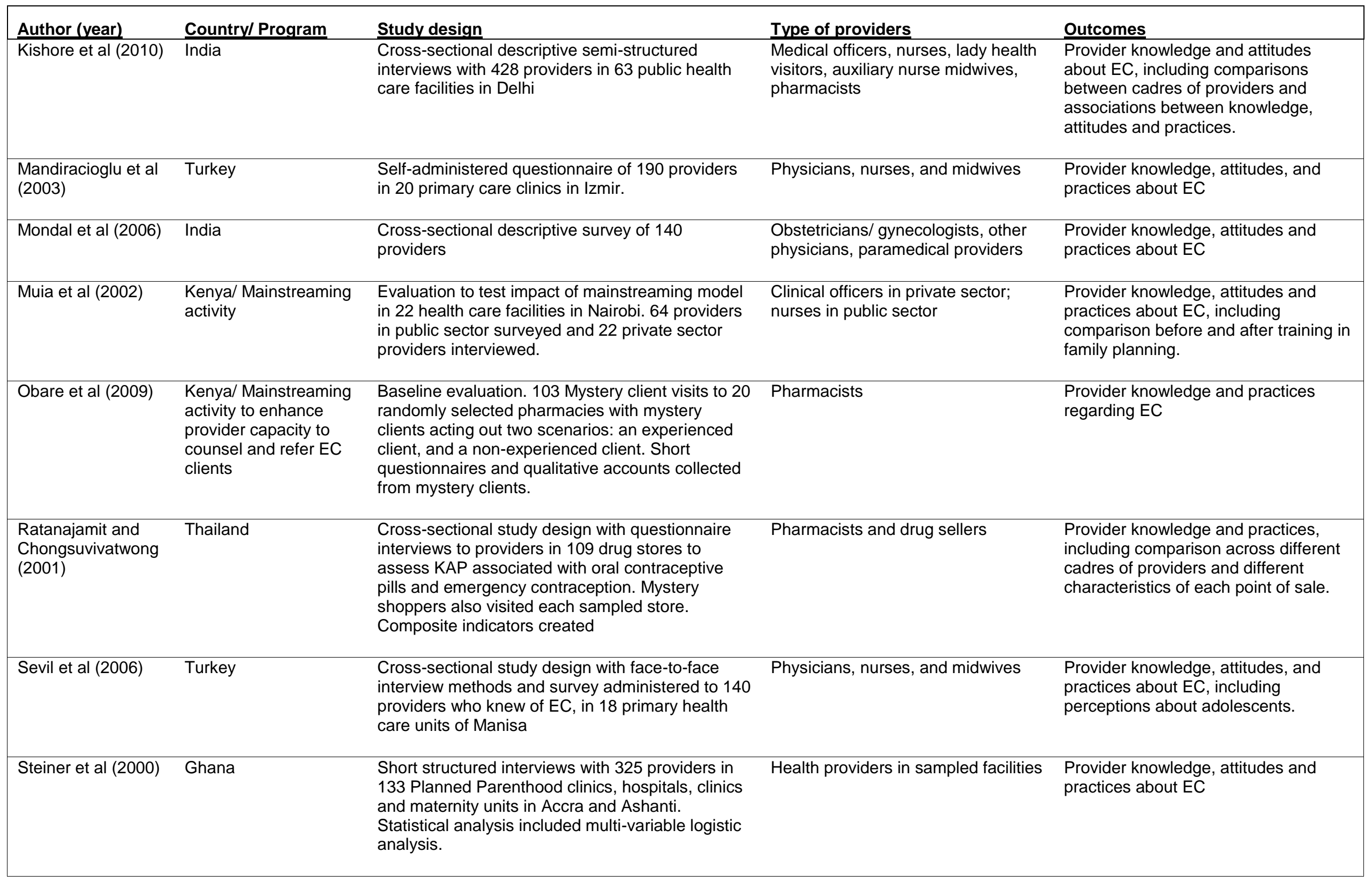




\begin{tabular}{|c|c|c|c|c|}
\hline Author (vear) & Country/ Program & Study design & Type of providers & Outcomes \\
\hline $\begin{array}{l}\text { Syahlul and Amir } \\
(2010)\end{array}$ & $\overline{\text { Indonesia }}$ & $\begin{array}{l}\text { Structured questionnaires to providers in } 36 \\
\text { community health centers and } 25 \text { private clinics, } \\
24 \text { hospitals, and } 8 \text { private clinics in Jakarta. } \\
\text { Providers selected using random sampling. Open- } \\
\text { ended questions included. }\end{array}$ & $\begin{array}{l}\text { General practitioners and } \\
\text { obstetricians }\end{array}$ & $\begin{array}{l}\text { Provider knowledge, attitudes and } \\
\text { practices about EC, including } \\
\text { associations between knowledge, } \\
\text { attitudes and practices. }\end{array}$ \\
\hline $\begin{array}{l}\text { Sychareun et al } \\
(2010)\end{array}$ & Laos & $\begin{array}{l}\text { In-depth interviews with } 10 \text { policy-makers, } 22 \\
\text { public sector providers, and } 10 \text { private providers. } \\
\text { Researchers conducted a manifest analysis. }\end{array}$ & $\begin{array}{l}\text { Physicians and nurses in family } \\
\text { planning and obstetrics/ gynecology } \\
\text { wards in public and private facilities }\end{array}$ & $\begin{array}{l}\text { Provider knowledge, attitudes and } \\
\text { practices about EC, including specifics } \\
\text { about KAP in area where EC is illegal. }\end{array}$ \\
\hline Tripathi et al (2003) & India & $\begin{array}{l}\text { Cross-sectional client and provider survey } \\
\text { (included provider-related information only in this } \\
\text { review) }\end{array}$ & $\begin{array}{l}\text { Obstetricians/ gynecologists, } \\
\text { general practitioners, paramedical } \\
\text { workers, medical students }\end{array}$ & $\begin{array}{l}\text { Provider knowledge, attitudes and } \\
\text { practices about EC, including } \\
\text { comparison of KAP among different } \\
\text { cadres of providers }\end{array}$ \\
\hline $\begin{array}{l}\text { Uzumer et al } \\
(2005)\end{array}$ & Turkey & $\begin{array}{l}\text { Cross-sectional survey administered via face-to- } \\
\text { face interviews with } 180 \text { providers of family } \\
\text { planning units in primary health care centers }\end{array}$ & Physicians, nurses, and midwives & $\begin{array}{l}\text { Provider knowledge, attitudes, and } \\
\text { practices about EC }\end{array}$ \\
\hline Yam et al (2007) & Barbados and Jamaica & $\begin{array}{l}\text { Interview-administered cross-sectional survey with } \\
228 \text { Jamaican providers and } 200 \text { Barbadian } \\
\text { providers. }\end{array}$ & $\begin{array}{l}\text { General practitioners, pharmacists, } \\
\text { obstetricians/ gynecologists, and } \\
\text { nurses }\end{array}$ & $\begin{array}{l}\text { Provider knowledge, attitudes and } \\
\text { practices about EC, including } \\
\text { comparisons between different cadres } \\
\text { of providers and effects of differing } \\
\text { country contexts. }\end{array}$ \\
\hline $\begin{array}{l}\text { Zeteroglu et al } \\
\text { (2004) }\end{array}$ & Turkey & $\begin{array}{l}\text { Cross-sectional survey of } 200 \text { providers in } \\
\text { university hospital of eastern Turkey }\end{array}$ & Physicians, nurses, and midwives & $\begin{array}{l}\text { Provider knowledge, attitudes, and } \\
\text { practices about EC }\end{array}$ \\
\hline
\end{tabular}

\section{Gray literature articles included in the review}

\begin{tabular}{|c|c|c|c|c|}
\hline Author (year) & Country/ Program & Study design & Type of providers & Outcomes \\
\hline Volle et al (2009) & $\begin{array}{l}\text { Albania/ Communication program to } \\
\text { create more supportive environment for } \\
\text { family planning }\end{array}$ & $\begin{array}{l}\text { Evaluation of campaign includes baseline and } \\
\text { endline evaluation in intervention and control } \\
\text { areas. Methods include face-to-face interviews } \\
\text { with providers and use of mystery clients to } \\
\text { assess provider attitudes and styles }\end{array}$ & Pharmacists & $\begin{array}{l}\text { Few qualitative outcomes on } \\
\text { provider knowledge and practices, } \\
\text { including comparison between } \\
\text { intervention and control sites }\end{array}$ \\
\hline $\begin{array}{l}\text { Khan and } \\
\text { Hossain (2008) }\end{array}$ & $\begin{array}{l}\text { Bangladesh/ Operations research } \\
\text { program to introduce EC into national } \\
\text { family planning program, including } \\
\text { training of providers. }\end{array}$ & $\begin{array}{l}\text { Evaluation of program included pre- post- design, } \\
\text { with surveys before training, } 2 \text { months after } \\
\text { training, and } 2 \text { years after training. Mystery clients } \\
\text { also implemented in } 27 \text { centers }\end{array}$ & $\begin{array}{l}\text { Medical staff and } \\
\text { paramedical staff }\end{array}$ & $\begin{array}{l}\text { Provider knowledge and practices, } \\
\text { including comparison between } \\
\text { different cadres of providers }\end{array}$ \\
\hline
\end{tabular}




\begin{tabular}{|c|c|c|c|c|}
\hline Author (year) & Country/ Program & Study design & Type of providers & Outcomes \\
\hline $\begin{array}{l}\text { Khan and } \\
\text { Hossain (2005) }\end{array}$ & $\begin{array}{l}\text { Bangladesh/ National scale-up activities } \\
\text { which include provider training }\end{array}$ & & $\begin{array}{l}\text { Medical staff and } \\
\text { paramedical staff }\end{array}$ & $\begin{array}{l}\text { Provider knowledge and } \\
\text { comparisons among trained and } \\
\text { untrained providers. }\end{array}$ \\
\hline Khan et al (2004) & $\begin{array}{l}\text { Bangladesh/ Final Report of Operations } \\
\text { Research to assess acceptability and } \\
\text { feasibility of providing EC through } \\
\text { paramedical providers. Provision of } \\
\text { information and services for } 9 \text { months. }\end{array}$ & $\begin{array}{l}\text { Project implemented in } 12 \text { health clinics in two } \\
\text { districts ( } 8 \text { intervention and } 4 \text { control). Pre- post- } \\
\text { design of three EC distribution models: EC on } \\
\text { demand; EC available in advance; control. } \\
\text { Evaluation of providers knowledge and practices } \\
\text { pre- and post-training of } 290 \text { providers }\end{array}$ & $\begin{array}{l}\text { All health providers, } \\
\text { including NGO outreach } \\
\text { workers and depot } \\
\text { workers }\end{array}$ & $\begin{array}{l}\text { Provider knowledge, attitudes, and } \\
\text { practices about EC, including long- } \\
\text { term retention of knowledge }\end{array}$ \\
\hline $\begin{array}{l}\text { Keesbury et al } \\
(2007)\end{array}$ & $\begin{array}{l}\text { Ethiopia/ Final Report of two-year pilot } \\
\text { project to mainstream EC in public } \\
\text { sector. }\end{array}$ & $\begin{array}{l}\text { Evaluation included analysis of service statistics, } \\
\text { and self-administered questionnaires to } 121 \\
\text { providers who attended training. }\end{array}$ & Nurses, midwives & $\begin{array}{l}\text { Provider knowledge, attitudes and } \\
\text { practices about EC, including those } \\
\text { concerning adolescent users. Effect } \\
\text { of training and associations } \\
\text { between KAP also analyzed. }\end{array}$ \\
\hline $\begin{array}{l}\text { Keesbury et al } \\
(2009)\end{array}$ & $\begin{array}{l}\text { Kenya/ Mainstreaming activity to improve } \\
\text { awareness about EC and strengthen } \\
\text { quality of EC services, focusing on } \\
\text { provision in pharmacies. Intervention } 18 \\
\text { months in duration and included } \\
\text { Contraceptive Technology Updates } \\
\text { (CTU) training. Baseline data from } \\
\text { Keesbury et al } 2007 \text {. }\end{array}$ & $\begin{array}{l}\text { Program evaluation included pre- and post- } \\
\text { surveys of } 74 \text { providers in CTU training facilities } \\
\text { and } 73 \text { providers in non-CTU facilities. }\end{array}$ & $\begin{array}{l}\text { Private sector } \\
\text { pharmacists }\end{array}$ & $\begin{array}{l}\text { Provider knowledge, attitudes and } \\
\text { practices about EC, including those } \\
\text { concerning adolescent users. Effect } \\
\text { of CTU training of providers } \\
\text { knowledge, attitudes and practices } \\
\text { also included. }\end{array}$ \\
\hline $\begin{array}{l}\text { Keesbury et al } \\
(2007)\end{array}$ & Kenya & $\begin{array}{l}\text { Data from National Diagnostic Assessment and } \\
\text { survey in } 199 \text { health facilities of } 5 \text { provinces. } \\
\text { Surveyed } 524 \text { providers and compared trained to } \\
\text { untrained providers. }\end{array}$ & $\begin{array}{l}\text { Physicians, clinical } \\
\text { officers, midwives, } \\
\text { nurses }\end{array}$ & $\begin{array}{l}\text { Provider knowledge, attitudes and } \\
\text { practices about EC, including effect } \\
\text { of training on providers. }\end{array}$ \\
\hline Khan et al (2007) & $\begin{array}{l}\text { India/ Comparison of two different } \\
\text { service-delivery models: } 1 \text { ) only } \\
\text { physicians receive training and provide } \\
\text { EC, 2) physicians and paraprofessionals } \\
\text { receive training and provide EC }\end{array}$ & $\begin{array}{l}\text { Evaluation includes pre- post-training survey of } \\
\text { providers, collection of service statistics, and } \\
\text { qualitative follow-up with EC clients. }\end{array}$ & $\begin{array}{l}\text { Physicians, } \\
\text { paraprofessional } \\
\text { medical providers }\end{array}$ & $\begin{array}{l}\text { Provider knowledge, attitudes and } \\
\text { practices about EC, including } \\
\text { comparison of different cadres of } \\
\text { providers and effects of training on } \\
\text { KAP. Also evaluated providers' } \\
\text { long-term retention of knowledge }\end{array}$ \\
\hline $\begin{array}{l}\text { McFayden et al } \\
\text { (2003) }\end{array}$ & South Africa & $\begin{array}{l}\text { Multi-center clinic-based situation analysis of EC } \\
\text { provision and utilization in public sector primary } \\
\text { health care facilities of } 3 \text { South African provinces. } \\
\text { Mystery clients as well as simulated client visits } \\
\text { were undertaken. }\end{array}$ & $\begin{array}{l}\text { Clinic managers and } \\
\text { nurses }\end{array}$ & $\begin{array}{l}\text { Provider knowledge, attitudes and } \\
\text { practices about } E C \text {, including those } \\
\text { concerning adolescents and } \\
\text { comparisons between urban and } \\
\text { rural areas. }\end{array}$ \\
\hline
\end{tabular}




\begin{tabular}{|c|c|c|c|c|}
\hline Author (vear) & Country/ Program & Study design & Type of providers & Outcomes \\
\hline $\begin{array}{l}\text { Association of } \\
\text { Obstetrics and } \\
\text { Gynecology of } \\
\text { Uganda (AOGU) } \\
\text { (2010) }\end{array}$ & $\begin{array}{l}\text { Uganda/ Training of trainers and of } \\
\text { providers in national referral hospitals } \\
\text { and regional referral hospitals. }\end{array}$ & $\begin{array}{l}\text { Evaluation included baseline and endline surveys } \\
\text { of trained providers, before and six months after } \\
\text { training }\end{array}$ & $\begin{array}{l}\text { Nurses, paramedics, } \\
\text { midwives, and medical } \\
\text { students }\end{array}$ & $\begin{array}{l}\text { Provider knowledge, attitudes and } \\
\text { practices about EC. }\end{array}$ \\
\hline $\begin{array}{l}\text { Skibiak et al } \\
\text { (2001) }\end{array}$ & $\begin{array}{l}\text { Zambia/ Research study provided } 4 \\
\text { different models of EC provision and } \\
\text { information to youth. Providers of } \\
\text { different models were trained and } \\
\text { instructed in order to identify } \\
\text { adolescents' preferences and barriers to } \\
\text { EC access }\end{array}$ & $\begin{array}{l}\text { Evaluation included observation, descriptive } \\
\text { accounts, and mystery clients within } 4 \text { different } \\
\text { models among } 37 \text { different scenarios }\end{array}$ & $\begin{array}{l}\text { Youth peers, } \\
\text { pharmacists, drug } \\
\text { vendors, community- } \\
\text { based shop-keepers, } \\
\text { health providers }\end{array}$ & $\begin{array}{l}\text { Provider attitudes and practices of } \\
\text { EC provision, focusing on those } \\
\text { concerning adolescent users. }\end{array}$ \\
\hline $\begin{array}{l}\text { Keesbury et al } \\
(2009)\end{array}$ & $\begin{array}{l}\text { Ethiopia/ Operations research study to } \\
\text { test feasibility of providing EC through } \\
\text { police stations to sexual violence } \\
\text { survivors. Intervention included training, } \\
\text { orientation of police officers, and module } \\
\text { and job aides for referral to health facility }\end{array}$ & $\begin{array}{l}\text { Evaluation included service provision data, survey } \\
\text { with } 210 \text { police officers ( } 25 \text { who had received } \\
\text { training) and focus group discussions. }\end{array}$ & Police officers & $\begin{array}{l}\text { Provider knowledge and practices, } \\
\text { as well as effects of training on } \\
\text { these characteristics. }\end{array}$ \\
\hline PATH (2004b) & $\begin{array}{l}\text { Global/ Newsletter reviewing multiple } \\
\text { projects in Cambodia, Nicaragua, and } \\
\text { Kenya where pharmacy-capacity to } \\
\text { provide EC was addressed }\end{array}$ & & Pharmacists & $\begin{array}{l}\text { Few findings from provider } \\
\text { knowledge and practices about EC } \\
\text { from individual evaluations. }\end{array}$ \\
\hline PATH (2004b) & $\begin{array}{l}\text { Global/ Article reviewing multiple projects } \\
\text { in Cambodia, Nicaragua and Kenya. } \\
\text { Highlights evaluation of some programs }\end{array}$ & $\begin{array}{l}\text { Pre- and post-training evaluations and mystery } \\
\text { clients }\end{array}$ & & $\begin{array}{l}\text { Few findings from provider } \\
\text { knowledge, attitudes, and practices } \\
\text { about EC from individual } \\
\text { evaluations }\end{array}$ \\
\hline
\end{tabular}




\section{(2) Population Council}

4301 Connecticut Ave. N.W. Suite 280

Washington, DC 20008

USA

Telephone: +1 2022379400

www.popcouncil.org 